\title{
The upstream/downstream movement paradox of lotic invertebrates: quantitative evidence from a Welsh mountain stream
}

\author{
D. DUDLEY- WILliams AND NANCY E, WILLIAMS \\ Division of Life Sciences, Scarborough Campus, University of Toronto, 1265 Milita y Trail, Scarborough, Ontario, Canada \\ M1C $1 A 4$
}

\begin{abstract}
SUMMARY
1. This study attempts to determine the mechanisms by which the downstream displacement of lotic invertebrates is compensated by the upstream movements of immatures and adults. To this end, submerged and aerial traps were set up at three sites, each $100 \mathrm{~m}$ apart, on a small mountain stream (Yr Ogof) in North Wales and operated for 12 months.

2. At Site 1 (the source), $19.3 \%$ of the benthic invertebrates lost as drift $w \in$ re replaced by the upstream movement of aquatic stages. At Site 2, the average upstream r mpensation was $51.1 \%$ (although there was a marked difference between the two traps a' 'he site). At downstream Site 3 the average compensation was 55.4\%. The net loss of benthos downstream over 1 year was estimated to be 261920 individuals from Site 1, 41891 from Site 2, and 40470 from Site 3.

3. At Sites 1 and 2, the numbers of invertebrates drifting were positively correlated with both current speed and water depth. At Sites 2 and 3, the numbers moving upstream were positively correlated with water temperature. At all three sites, the numbers of animals drifting were positively correlated with the numbers moving upstream, under water.

4. In none of the eight common species of stonefly did females show a strong overall upstream flight preference-however, two species, Leuctra nigra and Nemoura erratica, showed a significant downstream preference.

5. As with the stonefly nymphs, most of the caddisfly larvae showed a longitudinal distribution. Agapetus fuscipes larvae were most abundant at Site 1, yet females showed no preferred flight direction - this would seem to be inappropriate for maintaining this larval distribution pattern. However, females caught moving upstream at Site 2 were bigger and contained twice as many eggs, which were also larger, than females moving upstream at Site 1. The flight patterns of the other Trichoptera also seemed inappropriate for maintaining their respective larval distributions. Immature insects moved upstream at certain sites and times, but trends were not consistent. There was no correlation between female flight direction and local wind speed and direction.

6. Downstream displacement of the most abundant non-insect species, Gammarus pulex, was quite considerable at all three sites. However, at several times during the year the numbers moving upstream approached or exceeded those drifting. Maintenance of benthic population densities in this species is thought to be through a combination of upstream movement (which was highly correlated with benthic density at Sites 1 and 3) and production of young over a long (10 month) reproductive period. Maintenance of the benthic populations of the immature stages of the majority of insect species in Yr Ogof is thought to be through oviposition by females in the vicinity of their emergence sites.
\end{abstract}


7. Differences in density, size of individuals and life history were found among sites for several benthic species. The concept of optimal larval habitat is discussed in the context of longitudinal zonation and the flight behaviour of ovipositing females.

\section{Introduction}

Running water organisms live in a medium which is constantly moving past them, often quickly, and in one direction. This has resulted in the evolution of benthic rather than planktonic or nektonic forms, as the latter two modes of life require greater expenditure of energy in order to maintain station. Despite this, and for various reasons (see Williams \& Feltmate, 1992), many running water animals are displaced downstream by the current. This displacement (drift) may be more or less continuous in some species, whereas others are susceptible only at certain stages in their life cycles. Drift has been interpreted as being both beneficial (e.g. redistribution in response to competition for food or space, or dispersal of early instars; Hildrew \& Townsend, 1980; Walton, 1980) and detrimental (e.g. increased exposure to fish predators) to the benthic community in general. It has been calculated that over the period of their larval lives, some insects may drift as far as $10 \mathrm{~km}$ downstream (Hemsworth \& Brooker, 1979), although most species probably are not displaced to this extent.

The sheer numbers of organisms being transported downstream have led to speculation that headwater regions might become depopulated. Many lotic animals are positively rheotactic and tend to crawl against the current, but the distances moved and numbers of individuals moving that have been recorded in the literature seem generally insufficient to compensate for displacement through drift (e.g. Bishop \& Hynes, 1969a; Elliott, 1971; Benson \& Pearson, 1987). It has been proposed (Mottram, 1932; Müller, 1954, 1982) that, for insects, any loss from headwaters is counteracted by upstream dispersal and oviposition flights by newly emerged females. Evidence for such compensatory flights is highly variable (e.g. Madsen, Bengtsson \& Botz, 1973; Jones \& Resh, 1988) and, in several instances, the number of females flying upstream has been found to be only marginally greater than the numbers flying downstream. It has been argued that such small upstream gains are sufficient to restore headwater densities because of the high fecundity of single females.
Acceptance of the compensatory flight hypothesis is, on the large scale (measured in kilometres), attractive as it provides a convenient explanation as to why headwater benthic densities do not vary greatly from year to year. However, the hypothesis does not address the mechanism(s) by which non-insects maintain upstream populations, nor the fact that many benthic groups, including insects, exhibit strong longitudinal zonation from headwater to estuary with various taxa restricted to headwater, middle or lower reaches.

The purpose of this study was to attempt a holistic analysis of the upstream/downstream paradox by: (i) testing the applicability of the compensatory flight hypothesis to small-scale lotic systems through examination of emerging insect flight patterns in a stream in which the distribution of some species changed over just a few hundred metres; (ii) quantifying the compensation of drift by underwater upstream movements of the immature stages of insects and other benthic organisms; and (iii) comparing aspects of the ecology (specifically densities and life histories) of selected species, among adjacent sites, in order to identify variation that might promote longitudinal zonation.

\section{The study site}

Yr Ogof is a small stream arising at an altitude of $214 \mathrm{~m}$ a.s.l. in the Carneddau mountain range, Gwynedd, North Wales $\left(54^{\circ} 14^{\prime} \mathrm{N}, 4^{\circ} 00^{\prime} \mathrm{W}\right)$. Its primary source is a spring issuing from a rocky hollow, approximately $1 \mathrm{~m}$ wide, in the hillside. The hollow is filled with ferns (Filicales), nettles (Urtica dioica L.), stunted blackthorn bushes (Prunus spinosa L.) and grasses (Gramineae). Three sampling stations were set up: Site 1 was $10 \mathrm{~m}$ from the source. Here the substrate consisted of coarse sand and slate gravel with flat slate rocks up to $40 \mathrm{~cm}$ in diameter. The mean water depth was $3.5 \mathrm{~cm}$, the current, measured at a midstream reference point, ranged (annually) from 25 to $80 \mathrm{~cm} \mathrm{~s}^{-1}$ (over a 1:3 gradient) and the annual temperature range was $3.0-14.0^{\circ} \mathrm{C}$. Width of the channel was approximately $2.5 \mathrm{~m}$ although it was strongly 
braided. Site 2 was $100 \mathrm{~m}$ below Site 1 and had a 1:8 gradient. Substrate again consisted of coarse sand and gravel, but with a surface layer of more rounded cobbles $(\mathbf{1 5}-\mathbf{4 0} \mathrm{cm}$ in diameter) which were mostly covered with aquatic moss (Fontinalis antipyretica Hedw.). Mean water depth was $11 \mathrm{~cm}$, current ranged between 40 and $100 \mathrm{~cm} \mathrm{~s}^{-1}$, and, over the year, temperature ranged from 1.5 to $20^{\circ} \mathrm{C}$. Channel width was about $1 \mathrm{~m}$. The riparian vegetation at Sites 1 and 2 was similar, consisting mostly of heavily grazed pasture and marsh grasses (Juncus sp.), bracken (Pteridium aquilinum (L.)) and stunted blackthorn. In boggy patches, cottongrass (Eriophorum angustifolium Honck.), buttercup (Ranunculus sp.), flag iris (Iris pseudacorus L.) and sundew (Drosera rotundifolia L.) were common. Water parsnip (Berula erecta (Hudson)) was present on parts of the stream bed at both sites. In contrast to the very open nature of Sites 1 and 2, Site 3 was located just inside the upper boundary of a small wood. Here, 'approximately $120 \mathrm{~m}$ below Site 2 , the substrate was essentially the same as at Site 2, mean water depth was also $11 \mathrm{~cm}$, current ranged between 30 and $100 \mathrm{~cm} \mathrm{~s}^{-1}$, and water temperature varied between 4 and $20^{\circ} \mathrm{C}$. Gradient was approximately 1:6, and the channel was about $1.5 \mathrm{~m}$ wide. Riparian vegetation consisted of ash (Fraxinus excelsior L.), blackthorn, wild damson (Prunus domestica L.), holly (llex aquifolium L.), wild rose (Rosa canina L.), nettles, ferns and grasses.

\section{Materials and Methods}

Benthic densities of immature stages were obtained from three small Surber samples taken from randomly chosen sections of the bed at each site at 5 week intervals from August 1983 to July 1984. The area of stream bed enclosed by each sample was $250 \mathrm{~cm}^{2}$ and the depth of disturbance was $5 \mathrm{~cm}$, giving a substrate volume of $1250 \mathrm{~cm}^{3}$. Mesh size was $53 \mu \mathrm{m}$. Samples were preserved immediately in $10 \%$ formalin solution to which Rose Bengal dye had been added to facilitate sorting. In the laboratory, all invertebrates were separated from the inorganic/detritus residue, identified and counted. The density of each taxon at each site was expressed as a mean $\pm 1 \mathrm{SE}$.

Drift and upstream migrations of aquatic stages were measured at each site using two Hobbs \& Butler (1981) traps fitted with $250-\mu \mathrm{m}$ mesh nets. The design of this trap is such that it allows a 15-cm-wide section of bed and the entire water column above it to be sampled for drift and downstream-crawling animals concurrent with capture of animals swimming and crawling upstream over an adjacent $15-\mathrm{cm}$ section of bed and water column. At each site, two galvanized steel plates matching the dimensions of the trap bases were nestled into the bed (to a depth of $2 \mathrm{~cm}$ ) and permanently anchored with steel pegs. The two plates were placed about $5 \mathrm{~m}$ apart, longitudinally, in a manner that did not allow the traps to compromise one another. At approximately 2 week intervals from August 1983 to July 1984, traps were attached to the baseplates and were allowed to sample for 1-2 days. During this time, the traps were visited each day in order to ensure that the meshes were not clogged and flow through the net was not impeded. Water depth, current speed and temperature were measured at the time of trap installation, cleaning and emptying, and averaged for each sampling period. Trap contents were treated in the same way as the Surber samples.

Flying adults were trapped by means of a Malaise trap (Malaise, 1937) constructed from steel tubing and 1-mm-mesh fibreglass insect screening set up at each site. Each trap had a solid 2-cm-thick plywood base (1-m square) which was raised $10 \mathrm{~cm}$ above the mean water level, on steel posts, directly over the stream bed. This was to prevent insects from emerging directly under a trap and subsequently being collected without having shown any directional tendency in flight. The top of the plywood was camouflaged against the bed by covering it with natural substrate from the appropriate section of stream. Each trap had two openings, measuring $1 \times 1 \mathrm{~m}$, one facing directly downstream, the other directly upstream. A divider, made from screening, extended (at a right angle to the longitudinal axis of the stream) from the base to the tapered tip of the trap where a Plexiglass collecting device channelled insects into one of two jars containing $10 \%$ formalin solution-one for collecting and preserving insects moving upstream, the other for insects moving downstream. In order to be collected in the traps, adult insects had to have been travelling either upstream or downstream up to $1.1 \mathrm{~m}$ above the stream surface. Extensive bankside observations of emerging insects showed that very few adults flew higher than about $1 \mathrm{~m}$, presumably because of the open and breezy nature of the upper two sites. Mendl \& Miiller (1979) have shown the Malaise trap to be an effective method 
of collecting migrating adults in lotic systems.

The three flight traps were in continual operation from July 1983 to August 1984. Each was visited approximately every $4-6$ days, during which time the collecting jars were emptied and notes were made on weather conditions, particularly wind speed and direction, and air temperature. Because of the configuration of the small valley in which Yr Ogof lies, the wind direction was predominantly either upstream or downstream. Direction and relative wind speed over each collecting period were assessed using a vertical wire mesh fastened to each trap. Plastic ribbons with various small weights attached were tied to the ends of the mesh which was made sticky with double-sided tape. When a strong wind blew downstream, all the ribbons stuck, pointing downstream, to the mesh. When only a weak downstream wind blew, only the lightest ribbons stuck to the mesh. Wind speed determined in this way was calibrated against direct measurements made using soap bubbles.

In the laboratory, all adults were counted and identified to family. Because of the sheer numbers obtained, identification to species and sex was done only for the Trichoptera and Plecoptera. Females were separated into egg-bearing and 'spent' categories. Three abundant species of caddisfly and three species of stonefly were chosen for detailed analysis. In particular, for each species, direction of female flight was compared with the location of maximum densities of their respective larvae on the stream bed. Life histories were compared among sites. In addition, for the Trichoptera, adult female size and fecundity were examined in order to determine if these parameters varied with flight direction. The caddisflies chosen were Agapetus fuscipes Curtis, Philopotamus montanus (Donovan) and Potamophylax cingulatus (Stephens), and the stoneflies were Nemoura erratica Classen, Protonemura meyeri (Pictet) and Isoperla grammatica (Poda).

Normality and homogeneity of variance tests on the data indicated that transformation of the environmental measurements was necessary (KolmogorovSmirnov goodness of fit, $P<0.05 ; F$-max, $P>0.05$ ). Transformation to $\ln x$ satisfied the assumptions for parametric statistical analysis.

\section{Results}

Upstream/downstream movements in the water

Drift at Site 1 peaked during September and October, as recorded by both traps (Fig. 1). This coincided with a very marked drop in benthic density, from a mean of $6522 / 1250 \mathrm{~cm}^{3}$ of substrate $( \pm 1732,1 \mathrm{SE})$ measured on 2 September, to $1491 / 1250 \mathrm{~cm}^{3}( \pm 740)$ on 20 October. Upstream movement was high at the same time as the major drift event in mid-September. There was a significant positive correlation between the numbers drifting downstream and the numbers moving back upstream $(r=0.48$ and 0.59 for traps 1 and 2 , respectively; $P<0.05$ ). Over the year, based on data from twenty-seven sampling occasions, $19.3 \%$ of the animals displaced downstream $(19.6 \%$ and

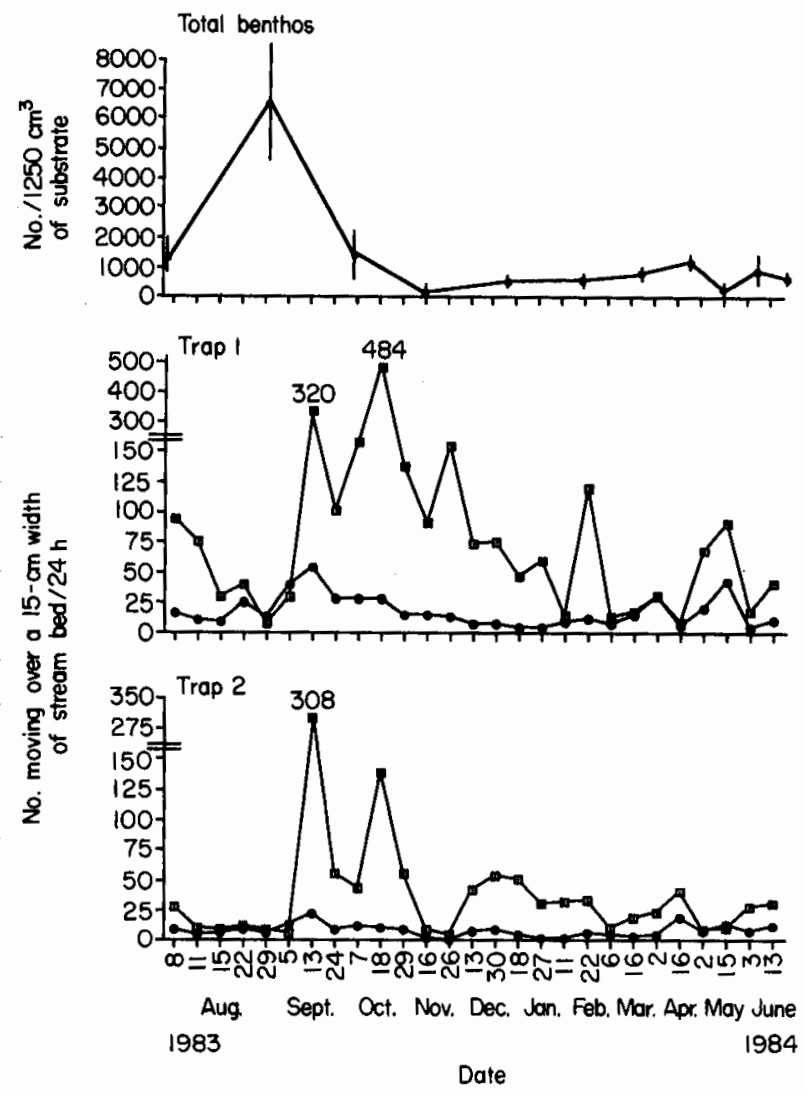

Fig. 1 Numbers of invertebrates drifting and crawling downstream over a $15-\mathrm{cm}$-wide section of bed and water column, and numbers moving upstream over an adjacent 15-cm section (over $24 \mathrm{~h}$ ) at Site 1 as measured on twenty-seven occasions over the period July 1983 to July $1984 . \square \square-$ Downstream; - - - upstream. Mean benthic densities are also shown ( \pm 1SE). 
Table 1 Overall compensation of invertebrates drifting downstream by those moving upstream, at the three sites. Each trap collected animals moving over two $15 \mathrm{~cm}$ wide sections of bed and water column. (Data are summed from twenty-seven sampling sessions, at each site, over the period August 1983 to July 1984; numbers of individuals captured are indicated in parentheses; *correlation significant at $P<0.05$ )

\begin{tabular}{|c|c|c|c|c|}
\hline \multirow[b]{2}{*}{ Site } & \multirow{2}{*}{$\begin{array}{l}\text { Trap } 1 \\
\% \text { (numbers) }\end{array}$} & \multirow{2}{*}{$\begin{array}{l}\text { Trap } 2 \\
\% \text { (numbers) }\end{array}$} & \multicolumn{2}{|c|}{$\begin{array}{l}\text { Correlation }(r) \\
\text { between numbers } \\
\text { drifting and } \\
\text { numbers moving } \\
\text { upstream }(n=27)\end{array}$} \\
\hline & & & Trap 1 & Trap 2 \\
\hline 1 & $19.6(2867)$ & $19.0(1230)$ & $0.48^{*}$ & $0.59^{*}$ \\
\hline 2 & $21.3(1428)$ & $80.8(1148)$ & $0.42^{*}$ & $0.68^{*}$ \\
\hline 3 & $51.6(1116)$ & $59.2(796)$ & $0.56^{*}$ & 0.27 \\
\hline
\end{tabular}

$19.0 \%$, as measured in Traps 1 and 2, respectively) were replaced by upstream movement (Table 1). Analysis of upstream/downstream movements of individual taxa showed that many more harpacticoid copepods and flatworms (Polycelis felina (Dalyell)) moved upstream than downstream (Table 2). Taxa in which over $40 \%$ of those individuals displaced downstream were replaced by upstream movement were the oligochaetes, the mayfly Baetis rhodani (Pict.) and the caddisfly Agapetus fuscipes. In about half of the taxa, upstream compensation was less than $25 \%$ lost to the drift.

Maximum drift at Site 2 occurred in mid-September and, again, this coincided with a drop in benthic density $\left(x=5510 / 1250 \mathrm{~cm}^{3} \pm 1095\right.$ on September, to $1378 \pm 481$ on the 20 October) (Fig. 2). A lesser drift peak was recorded in Trap 1 on 12 December. Again there was a significant correlation $(P<0.05)$ between the numbers drifting downstream and those moving back upstream as measured in both traps $(r=0.42$ and 0.68 , Traps 1 and 2, respectively; Table 1). Over the year, $21.3 \%$ of the animals displaced downstream in the region of Trap 1 were replaced by upstream movement whereas, in the region of Trap 2, over $80 \%$ of the animals lost were replaced (Table 1). Both species of flatworm moved upstream in greater numbers than drifted downstream (Table 2). Taxa in which more than $50 \%$ of the individuals drifting downstream were replaced by upstream movement were harpacticoids, Gammarus pulex (L.), mayflies (especially B. rhodani), simuliids, chironomids and
Table 2 Percentage compensation of the numbers of invertebrates (most abundant taxa only) drifting downstream by those moving upstream, as measured over a $60 \mathrm{~cm}$ wide section of bed and water column, at each site. (Data are summed from twenty-seven sampling sessions; at each site, over the period August 1983 to July 1984; numbers of individuals captured are indicated in parentheses; - , fewer than 10 individuals collected)

\begin{tabular}{lccc}
\hline & $\begin{array}{l}\text { Site } 1 \\
\% \text { (numbers) }\end{array}$ & $\begin{array}{l}\text { Site } 2 \\
\% \text { (numbers) }\end{array}$ & $\begin{array}{l}\text { Site } 3 \\
\% \text { (numbers) }\end{array}$ \\
\hline Taxon & $192.2(149)$ & $225.0(13)$ & - \\
\hline Polycelis felina & $33.9(150)$ & $133.3(42)$ & - \\
Crenobia alpina & $48.5(49)$ & $45.0(58)$ & $22.1(177)$ \\
Oligochaeta & $275.0(30)$ & $100.0(20)$ & - \\
Harpacticoida & $11.4(176)$ & $2.9(72)$ & $50.0(30)$ \\
Ostracoda & $16.5(2117)$ & $56.5(867)$ & $61.8(1047)$ \\
Ganimarus pulex & $29.3(53)$ & $9.7(34)$ & - \\
Acari & $22.0(349)$ & $30.7(324)$ & $70.1(148)$ \\
Collembola & $42.8(207)$ & $88.3(785)$ & $31.5(533)$ \\
Baetis rhodani & - & $50.0(30)$ & $66.7(20)$ \\
other Ephemerop. & $29.3(150)$ & $19.5(98)$ & $62.5(52)$ \\
Plecoptera & $63.6(193)$ & $30.0(26)$ & $37.5(33)$ \\
Agapetus fuscipes & $22.4(170)$ & $23.9(83)$ & $85.7(26)$ \\
other cased Trichop. & $22.3(104)$ & $7.3(59)$ & $31.8(29)$ \\
Diplectrona felix & $25.3 .5(22)$ & $18.2(26)$ & $50.0(24)$ \\
other caseless Trich. & $37.5(2)$ &.- \\
Dicranota sp. & $10.9(61)$ & $8.3(13)$ & - \\
Perioma sp. & $9.7(113)$ & - & - \\
Simuliidae & $33.3(44)$ & $55.9(92)$ & $72.9(83)$ \\
Chironomidae & $16.2(820)$ & $51.0(468)$ & $56.6(399)$ \\
other Diptera larvae & $21.3(80)$ & $14.7(40)$ & $80.0(27)$ \\
Elminthidae & - & $86.7(28)$ & $36.4(18)$ \\
\hline
\end{tabular}

elminthid beetles. Taxa in which compensation was particulary weak included ostracods, mites, caseless caddisflies (especially Diplectrona felix McLachlan) and certain Diptera.

At Site 3, drift peaks were associated with a drop in benthic density (from $3340 / 1250 \mathrm{~cm}^{3} \pm 655$ in early August to $498 \pm 87$ on 20 October) but occurred over a longer time (mid-August to mid-October) (Fig. 3). Correlation between upstream movement and drift at Site 3 was only significant for the data collected in Trap $1(r=0.56)$. Over the year, an average of $55.4 \%$ of drifting individuals were replaced (Table 1). Taxa exhibiting strong upstream compensation $(>50 \%)$ at this site wère ostracods, G. pulex, Collembola, nonbaetid mayflies, Plecoptera, some cased and caseless Trichoptera, simuliids, chironomids and other Diptera (Table 2).

In terms of total invertebrates, the net loss of aquatic stages downstream over a period of 1 year was 261920 individuals from Site 1, 41891 from Site 

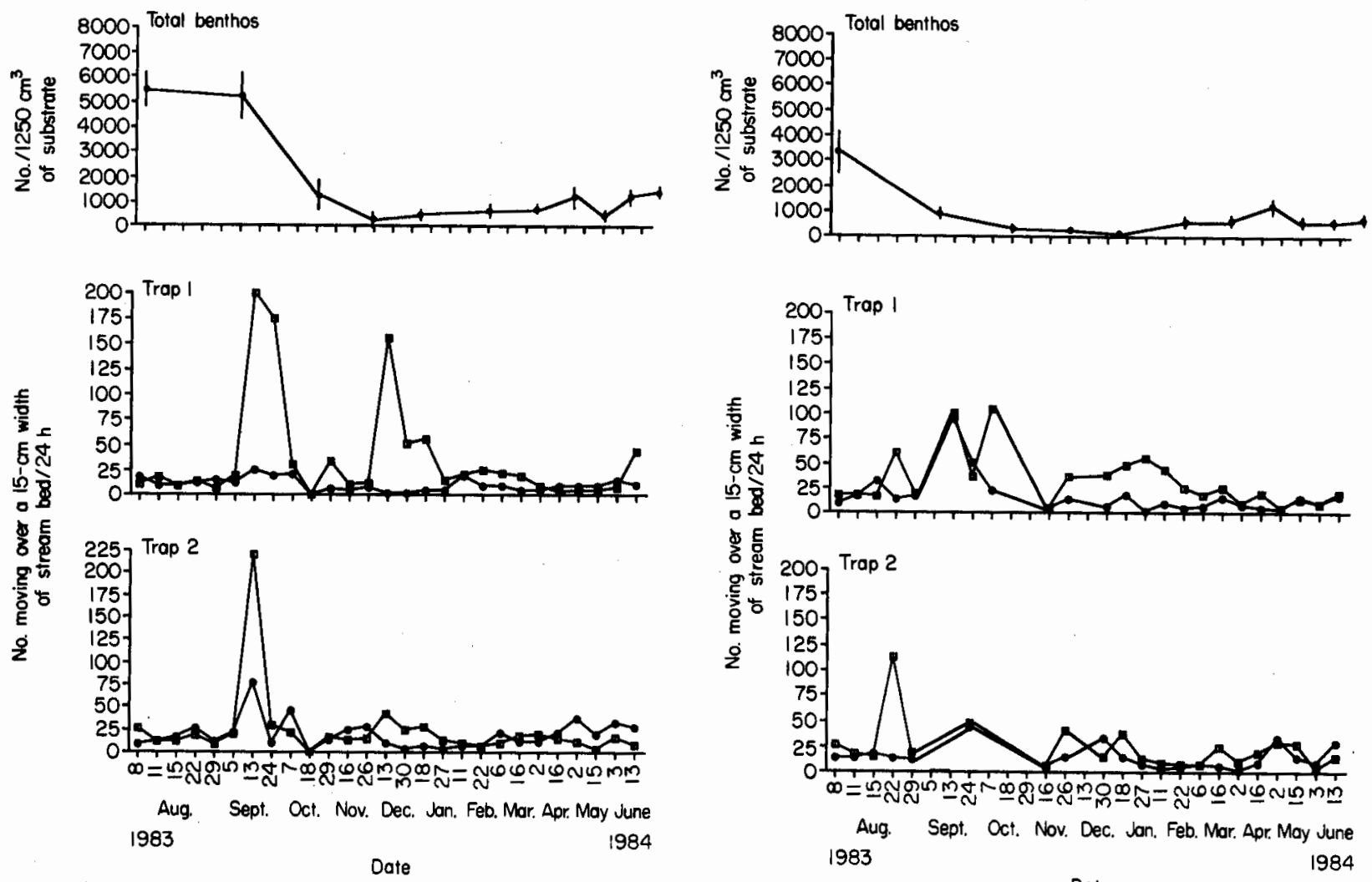

Fig. 2 Numbers of invertebrates drifting and crawling downstream over a $15-\mathrm{cm}$-wide section of bed and water column, and numbers moving upstream over an adjacent 15-cm section (over $24 \mathrm{~h}$ ) at Site 2 as measured on twenty-seven occasions over the period July 1983 to July 1984 . - $\square-$, Downstream; - - upstream. Mean benthic densities are also shown ( $\pm 1 \mathrm{SE})$.

2, and 40470 from Site 3 . These estimates were made by extrapolating the numbers caught in the drift traps, minus those caught in the upstream traps, during the twenty-seven sampling occasions (covering 39 days) to 365 days and then multiplying the totals by the ratio of stream width to trap opening. Unknown quantities in these calculations were the distances covered by individuals while drifting or moving upstream. At best, these estimates represent the movement dynamics around a single transect line across each site, and are therefore useful for comparative purposes. However, they do not, for example, allow us to determine the total movement into or out of a given area of stream bed.

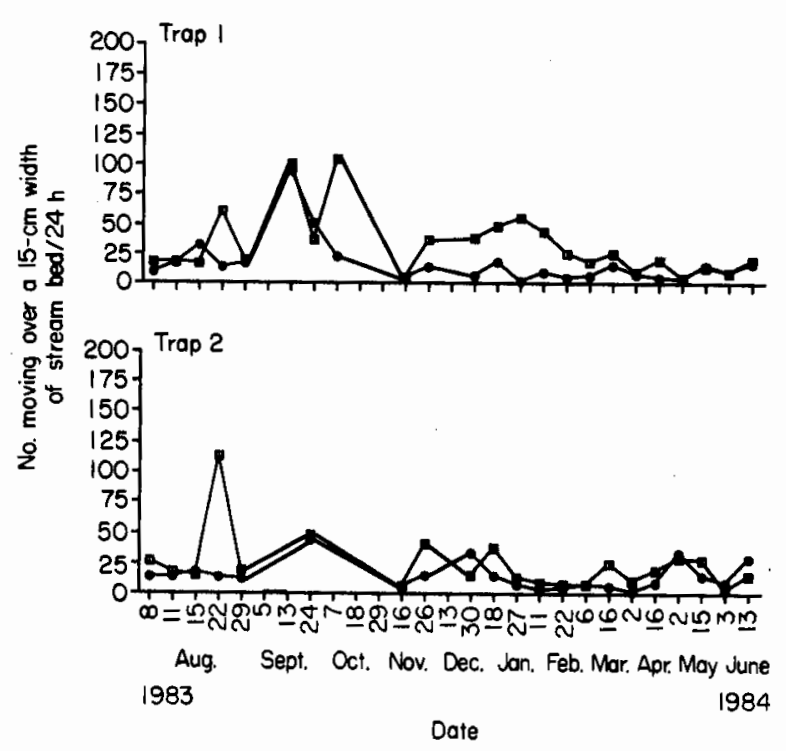

Fig. 3 Numbers of invertebrates drifting and crawling downstream over a $15-\mathrm{cm}$-wide section of bed and water column, and numbers moving upstream over an adjacent 15$\mathrm{cm}$ section (over $24 \mathrm{~h}$ ) at Site 3 as measured on twenty-seven occasions over the period July 1983 to July $1984 .-\square-$,

Downstream; - - upstream. Mean benthic densities are also shown $( \pm 1 \mathrm{SE})$.

\section{Movements above the water}

Ratios of the numbers of adult insects moving upstream to the numbers moving downstream for the dominant orders and families are shown in Table 3. These ratios were calculated from the total emergence counts at each site over 13 months and represent combined sexes. There are very few obviously consistent patterns. Strong upstream movement was evident among the Diptera, particularly at Site 1 and to some degree at Site 3. However, several families (Chironomidae, Dolichopodidae, Psychodidae and Rhagionidae) moved predominantly downstream at Site 2. The Trichoptera also tended to move downstream at Site 2 but upstream at Sites 1 and 3 . Stoneflies showed greater movement downstream at Sites 1 and 3. Too few mayfly adults were caught to justify conclusions being drawn. 
Table 3 Numbers of adult insects caught, moving either upstream or downstream. by the Malaise traps from July 1983 to August 1984. + and - indicate significant $(P<0.05)$ upstream and downstream movement biases, respectively (based on significant departures from a 1:1 ratio, determined from a Binomial test, where $P=Q=0.5$ )

\begin{tabular}{llrrlll}
\hline Site & Taxon & Upstream & Downstream & Ratio (up:down) & Bias & $z$ score \\
\hline 1 & Ephemeroptera & 2 & 1 & & & Too few \\
2 & & 2 & 34 & $0.06: 1$ & - & 12.0 \\
3 & & 13 & 31 & $0.42: 1$ & - & 3.2 \\
1 & Plecoptera & 215 & 382 & $0.56: 1$ & - & 7.2 \\
2 & & 530 & 579 & $0.92: 1$ & & 1.5 \\
3 & & 444 & 525 & $0.85: 1$ & - & 2.7 \\
1 & Trichoptera & 462 & 395 & $1.17: 1$ & + & 2.3 \\
2 & & 917 & 1268 & $0.72: 1$ & - & 7.6 \\
3 & & 526 & 357 & $1.47: 1$ & + & 5.8 \\
1 & Chironomidae & 1581 & 825 & $1.92: 1$ & + & 16.3 \\
2 & & 1907 & 2164 & $0.88: 1$ & - & 4.1 \\
3 & & 1224 & 1403 & $0.87: 1$ & - & 3.4 \\
1 & Dolichopodidae & 445 & 194 & $2.29: 1$ & + & 10.8 \\
2 & & 694 & 1088 & $0.64: 1$ & - & 9.6 \\
3 & & 412 & 284 & $1.45: 1$ & + & 4.9 \\
1 & Psychodidae & 1064 & 784 & $1.36: 1$ & + & 6.6 \\
2 & & 811 & 1103 & $0.74: 1$ & - & 6.8 \\
3 & & 1048 & 834 & $1.26: 1$ & + & 5.0 \\
1 & Rhagionidae & 16 & 3 & $5.33: 1$ & + & 3.8 \\
2 & & 38 & 78 & $0.49: 1$ & - & 4.1 \\
3 & & 32 & 26 & $1.23: 1$ & & 0.7 \\
1 & Thaumaleidae & 68 & 65 & $1.05: 1$ & & 0.2 \\
2 & & 59 & 37 & $1.59: 1$ & + & 2.2 \\
3 & & 21 & 11 & $1.91: 1$ & & 1.7 \\
1 & Tipulidae & 284 & 257 & $1.11: 1$ & & 1.1 \\
2 & & 218 & 215 & $1.01: 1$ & & 1.0 \\
3 & & 183 & 148 & $1.24: 1$ & & 1.4 \\
\hline & & & & & &
\end{tabular}

Table 4 Upstream:downstream flight tendencies in females of the most common species of Plecoptera and Trichoptera found in $Y r$ Ogof (all dates and sites combined). + and - indicate significant $(P<0.05)$ upstream and downstream movement biases, respectively (based on significant departures from a 1:1 ratio, determined from a Binomial test, where $P=Q=0.5$ )

\begin{tabular}{|c|c|c|c|c|c|}
\hline Species & Upstream & Downstream & Ratio (up:down) & Bias & $z$ score \\
\hline \multicolumn{6}{|l|}{ Plecoptera } \\
\hline Leuctra nigra (Olivier) & 70 & 107 & $0.65: 1$ & - & 2.9 \\
\hline Nemoura erratica (Claassen) & 142 & 230 & $0.62: 1$ & - & 4.7 \\
\hline Brachyptera risi (Morton) & 26 & 40 & $0.65: 1$ & & 1.9 \\
\hline Protonenura meyeri (Pictet) & 84 & 109 & $0.77: 1$ & & 1.9 \\
\hline Siphonoperla torrentium (Pictet) & 45 & 40 & $1.31: 1$ & & 0.4 \\
\hline Isoperla grammatica (Poda) & 174 & 159 & $1.09: 1$ & & 0.8 \\
\hline Nenurella pictetii Klapálek & 95 & 116 & $0.82: 1$ & & 1.5 \\
\hline Amphinemura sulcicollis (Stephens) & 34 & 41 & $0.83: 1$ & & 0.9 \\
\hline \multicolumn{6}{|l|}{ Trichoptera } \\
\hline Silo pallipes (Fabricius) & 32 & 13 & $2.54: 1$ & + & 3.0 \\
\hline Philopotanius montanus (Donovan) & 368 & 717 & $0.52: 1$ & - & 11.2 \\
\hline Potamophylax cingulatus (Stephens) & 26 & 41 & $0.64: 1$ & - & 2.0 \\
\hline Tinodes assinilis McLachlan & 18 & 33 & $0.53: 1$ & - & 2.4 \\
\hline Rhyacophila dorsalis (Curtis) & 37 & 24 & $1.42: 1$ & & 1.3 \\
\hline Chaetopteryx villosa (Fab.) & 24 & 14 & $1.71: 1$ & & 1.5 \\
\hline Wormaldia occipitalis (Pict.) & 23 & 21 & $1.14: 1$ & & 0.2 \\
\hline Diplectrona felix McL. & 71 & 80 & $0.88: 1$ & & 0.8 \\
\hline Agapetus fuscipes Curtis & 220 & 188 & $1.17: 1$ & & 1.5 \\
\hline Beraea maurus (Curtis) & 143 & 117 & $1.22: 1$ & & 1.6 \\
\hline
\end{tabular}




\section{Plecoptera}

Fourteen species of Plecoptera were caught in the flight traps. Eight of these were collected in sufficient numbers to calculate meaningful overall upstream:downstream ratios (Table 4). Only two species showed biased directional flight.

Details of the directional movements of adults of five abundant species, together with the distribution of nymphal density among sites, are given in Fig. 4 . There was evidence of longitudinal zonation among some species. For example, Nemurella pictetii Klapálek nymphs were found primarily at Site 1; however; females did not show any significant flight direction tendency. The bulk of the nymphs of Nemoura erratica was found at Site 1, yet females trapped both here and at Site 2 were moving primarily downstream. Nymphs of Protonemoura meyeri occurred at all three sites, but were most abundant at Site 2 where there were aquatic mosses. Females showed no flight direction preference at any site. Female Isoperla grammatica also showed no preference, although the highest densities of nymphs occurred at Site 2. Siphonoperla torrentium (Pictet) showed no flight direction preference and nymphs were fairly evenly distributed among all three sites. Very few nymphs of Brachyptera risi (Morton), Amphinemura sulcicollis (Stephens) and Leuctra nigra (Olivier) were found; however, females of the latter species showed a pronounced tendency to fly downstream.

\section{Trichoptera}

Twenty-one species of Trichoptera were caught at the three sites. Directional movements of females and larval densities of the nine most abundant species are shown in Fig. 5. As with the stoneflies, a longitudinal zonation of the larvae on the stream bed was evident. Agapetus fuscipes larvae were most abundant at Site 1 , but there was no predominant flight direction of females. In contrast, most females of Tinodes assimilis McLachlan at Site 2 flew downstream, which would seem inappropriate for maintenance of larvae at Site 1. Larvae of Diplectrona felix occurred predominantly at Sites 1 and 2, but no flight direction preference was shown by the females. Potamophylax cingulatus larvae were most abundant at Site 2. Both here and at Site 1, females tended to fly downstream. Female Philopotamus montanus at
Site 2 also flew predominantly downstream but showed no preference in flight direction at the other two sites. Larvae were most abundant at Sites 2 and 3. Silo pallipes (Fabricius) flew predominantly upstream at Sites 2 and 3, yet most of its larvae were collected at Site 3. None of the other trichopterans showed any flight direction preference. Overall upstream:downstream ratios for the 10 most common caddisfly species are summarized in Table 4 .

\section{Correlation between movements and environmental variables}

At Sites 1 and 2, the numbers of invertebrates drifting were positively correlated with both stream depth and current speed, but there was no such relationship at Site 3 (Table 5). As might be expected, depth and current speed were highly correlated at all three sites. At Site 2, the numbers of invertebrates moving upstream were positively correlated with maximum and minimum water temperatures (the latter two being correlated). At Site 3, upstream movement was positively correlated with minimum water temperature alone.

One of the most obvious environmental factors that might have influenced upstream:downstream flight patterns was wind. However, a regression analysis of female numbers and flight direction (positive numbers $=$ upstream, negative numbers $=$ downstream) against wind speed and direction (positive $=$ blowing upstream, negative $=$ blowing downstream) was not significant $(r=0.002, P=0.98)$.

\section{Comparison of insect abundance and life histories among sites}

As previously noted, most of the nymphs of Nemoura erratica were found at Site 1 . Very small nymphs were first detected here in late July, but at this time they could not be distinguished from other nemourids. By early January the nymphs were identifiable and final instars appeared from mid-April into July, coincident with the appearance of adults. Development appeared to be much the same at the other two sites, although some of the downstream nymphs were occasionally larger (Fig. 6). The emergence period was longer downstream.

Nymphs of Protonemura meyeri were most common at Sites 2 and 3 . Although large numbers of small 
Fig. 4 Longitudinal zonation of the five most abundant stonefly species across the three sampling sites (expressed as percentage occurrence at each site, based on the total number of nymphs collected). Arrows indicate the directions in which adult females flew. Large arrows indicate that at least $66 \%$ of the females moved in that direction at that site. Ratios of the numbers of males:females are given for each site, as are the overall ratios of the numbers of females moving upstream:numbers of females moving downstream (all sites combined).

Table 5 Matrix of partial correlation coefficients relating the total numbers of invertebrates drifting or moving upstream to measured environmental variables (each comparison is based on twenty-seven measurements over the period July 1983 to August 1984; *correlation significant at $P<0.05$ )

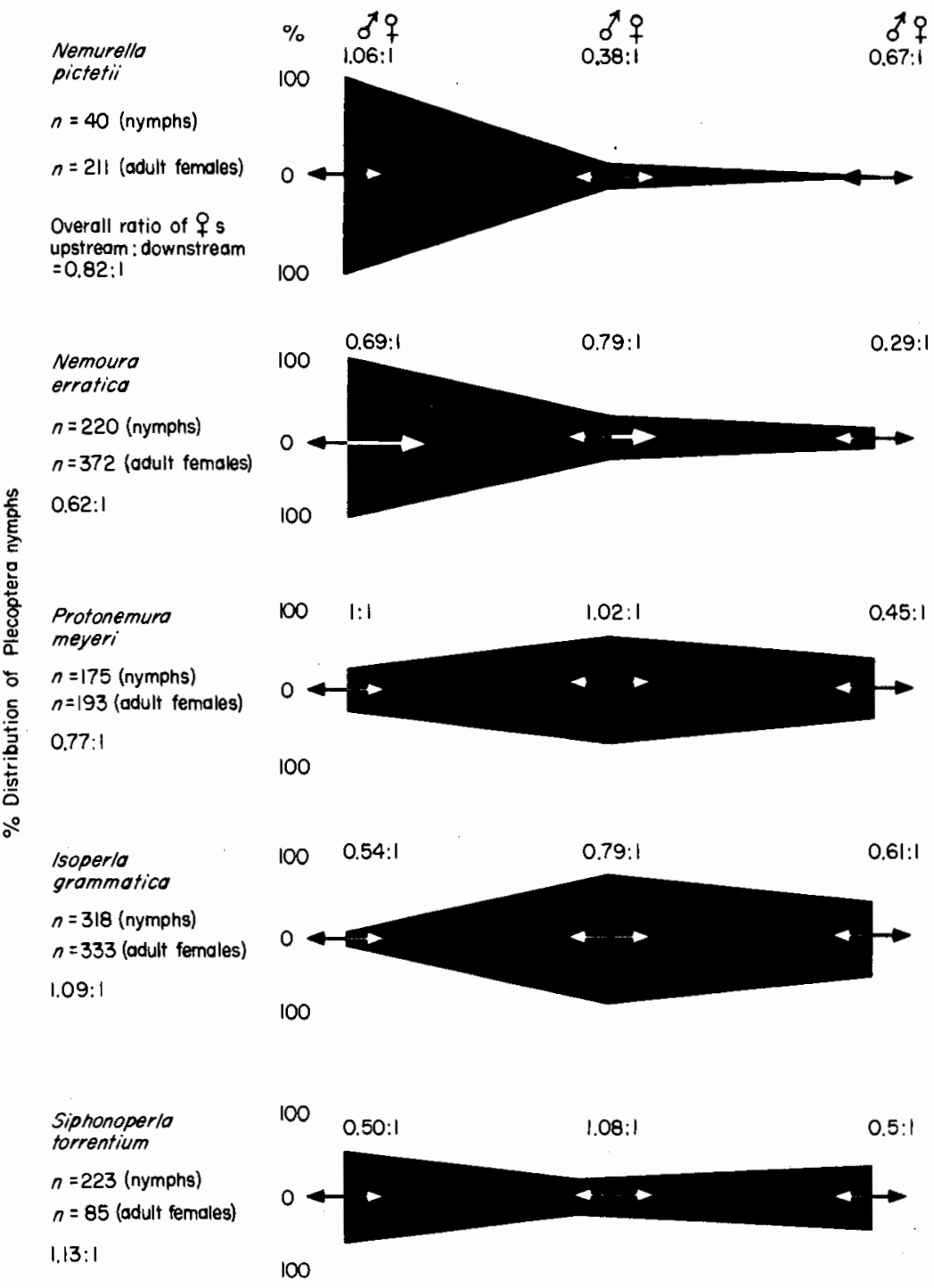

\begin{tabular}{lccc}
\hline Environmental variable & Numbers drifting & Numbers moving upstream & Site \\
\hline Current $\left(\mathrm{cm} \mathrm{s}^{-1}\right)$ & $0.436^{*}$ & 0.010 & 1 \\
Depth $(\mathrm{cm})$ & $0.524^{*}$ & 0.116 & 1 \\
Min. water temp. $\left({ }^{\circ} \mathrm{C}\right)$ & -0.182 & 0.110 & 1 \\
Max. water temp. $\left({ }^{\circ} \mathrm{C}\right)$ & -0.132 & 0.189 & 1 \\
Current $\left(\mathrm{cm} \mathrm{s}^{-1}\right)$ & $0.656^{*}$ & -0.011 & 2 \\
Depth $(\mathrm{cm})$ & $0.611^{*}$ & 0.036 & 2 \\
Min. water temp. $\left({ }^{\circ} \mathrm{C}\right)$ & 0.047 & $0.419^{*}$ & 2 \\
Max. water temp. $\left({ }^{\circ} \mathrm{C}\right)$ & -0.241 & $0.420^{*}$ & 2 \\
Current $\left(\mathrm{cm} \mathrm{s}^{-1}\right)$ & 0.015 & -0.174 & 3 \\
Depth $(\mathrm{cm})$ & -0.051 & -0.152 & 3 \\
Min. water temp. $\left({ }^{\circ} \mathrm{C}\right)$ & 0.081 & $0.549^{*}$ & 3 \\
Max. water temp. $\left({ }^{\circ} \mathrm{C}\right)$ & -0.086 & 0.359 & 3 \\
\hline
\end{tabular}




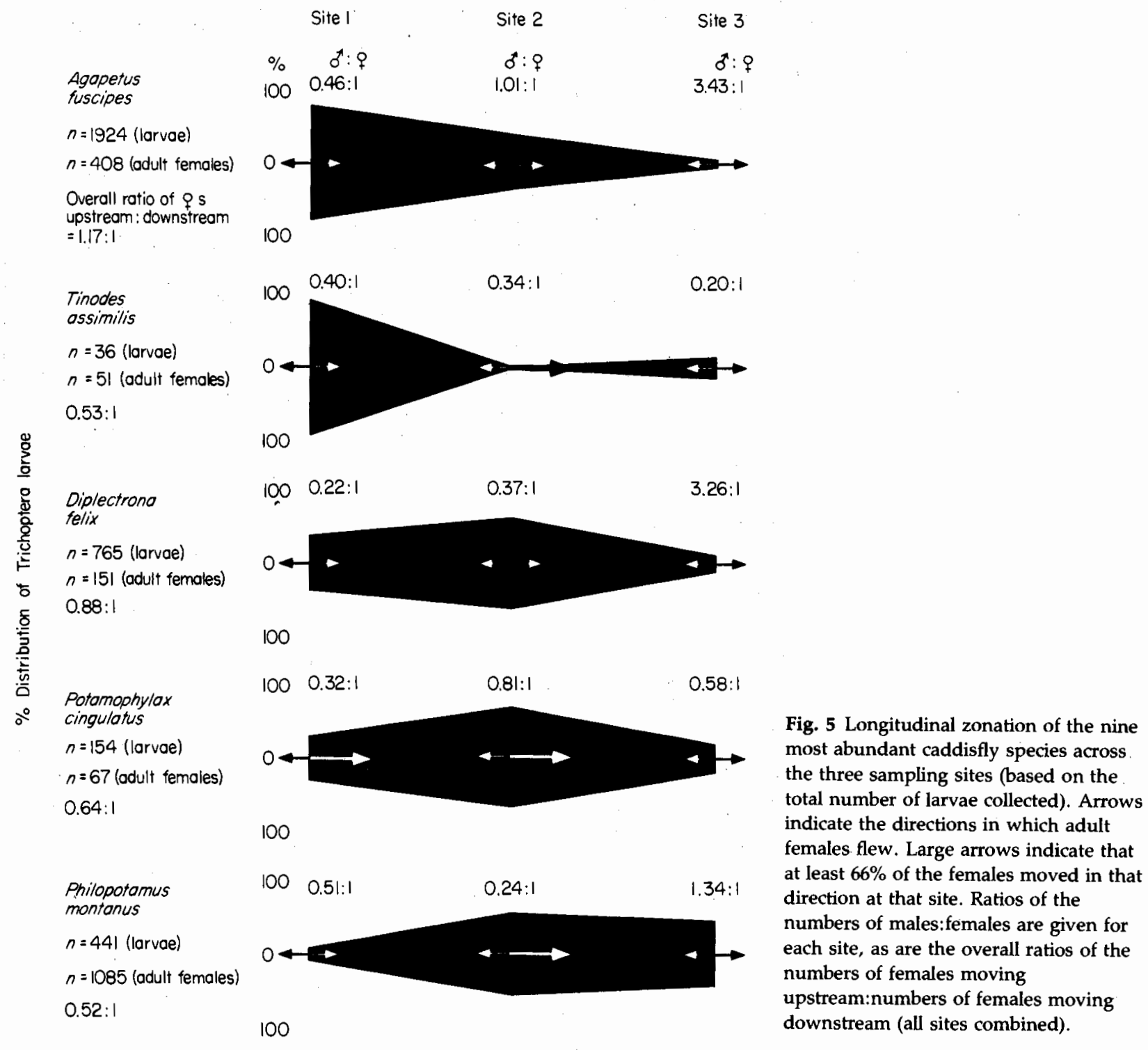

nymphs were evident from July to September, subsequent densities of larger nymphs were low (Fig. 7). At Site 1, nymphs had disappeared completely by October, which might suggest that they had been displaced downstream were it not for the fact that final instars were collected at Site 1 the previous July. Occurrence of early instar nymphs, sporadically, through the year at Sites 2 and 3 was probably a consequence of the very long emergence period of the adults. Final instar nymphs were the same size at all three sites.

Although few nymphs of Isoperla grammatica occurred at Site 1, it appeared to be possible to complete a life cycle there (Fig. 8). Most nymphs occurred at the two downstream sites where periods of maximal nymphal growth often did not coincide. Emergence times were similar at all three sites although adults appeared earliest at Site 2 and disappeared soonest at Site 1.

Females of Agapetus fuscipes caught moving upstream at Site 2 were bigger and contained eggs that were larger and twice as abundant compared with those of females moving upstream at Site 1 (Table 6).

Comparison of the life history of $A$. fuscipes at the three sites showed that: (i) larvae developed over the period September to July at Site 1, with adults emerging from late April to mid-October; (ii) larvae at Sites 2 and 3 took longer to develop (from late July 
Fig. 5 (continued)

Table 6 Comparison of the females of three species of caddisfly caught while moving upstream or downstream at the three sites: Agapetus fuscipes, upstream during the 29 June - 7 July 1984 sampling period; Philopotamus montanus, upstream during the 19 May - 3 June 1984 sampling period; and Potamophylax cingulatus, downstream during the 25 September 1984 sampling period (numbers of females examined are indicated in brackets; difference within pairs marked *, and ${ }^{\ddagger}$ is significant at $P<0.05$, from $t$-tests)
Rhyacophila dorsalis

$n=113$ (larvae) $n=61$ (adult females)

Overall ratio of $q \mathrm{~s}$ upstream: downstream $=1.42: 1$

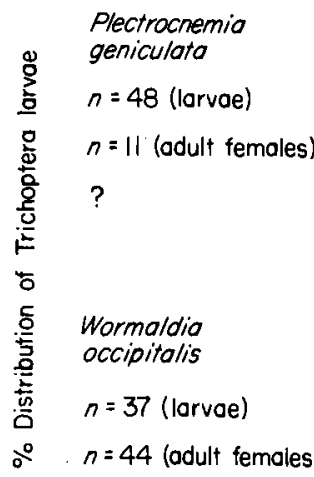

I. $14: 1$

Silo

pallipes

$n=38$ (larvae)

$n=45$ (adult femoles)

2.54:1

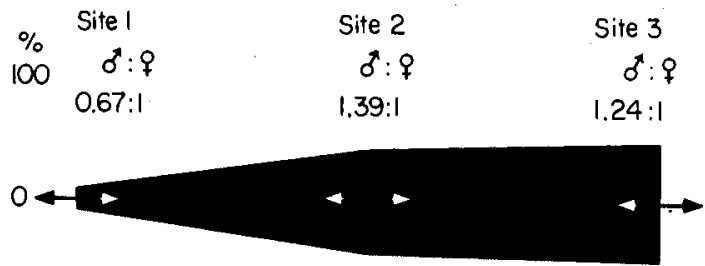

100

100 ?

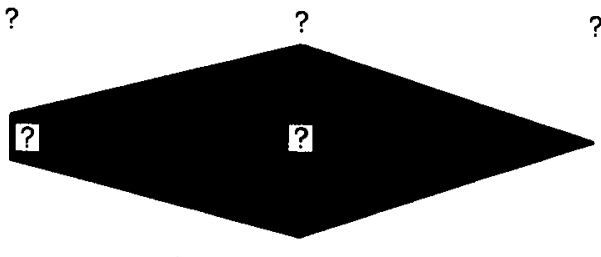

100

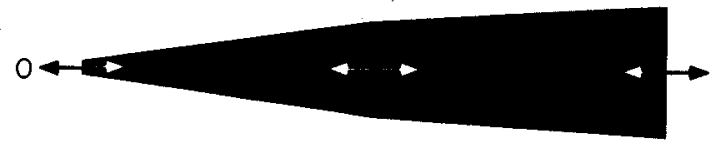

100

$100 ?$

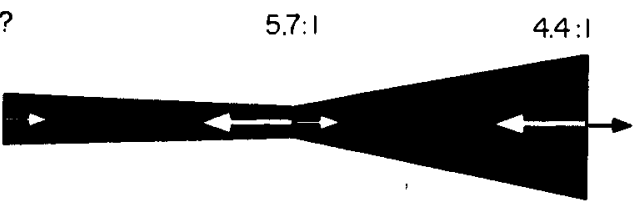

0

100

\begin{tabular}{|c|c|c|c|}
\hline & $\begin{array}{l}\text { Site } 1 \\
(\bar{x}+1 \mathrm{SE})\end{array}$ & $\begin{array}{l}\text { Site } 2 \\
(\bar{x}+1 \mathrm{SE})\end{array}$ & $\begin{array}{l}\text { Site } 3 \\
(\bar{x}+1 \mathrm{SE})\end{array}$ \\
\hline \multicolumn{4}{|l|}{$\begin{array}{l}\text { Head capsule } \\
\text { width (mm) }\end{array}$} \\
\hline A. fuscipes & $0.63 \pm 0.02(13)^{*}$ & $0.70 \pm 0.02(15)^{*}$ & Insufficient no. \\
\hline P. montanus & $1.90 \pm 0.04(3)$ & $1.72 \pm 0.04(15)$ & $1.72 \pm 0.03(10)$ \\
\hline P. cingulatus & $2.31 \pm 0.04(9)$ & $2.34 \pm 0.03(5)$ & Insufficient no. \\
\hline \multicolumn{4}{|l|}{ No. eggs/female } \\
\hline A. fuscipes & $20.8 \pm 4.6(6)^{\dagger}$ & $55.4 \pm 9.6(10)^{\dagger}$ & Insufficient no. \\
\hline P. montanus & Insufficient no. & $150.3 \pm 19.0(10)^{*}$ & $253.8 \pm 30.2(10)^{*}$ \\
\hline P. cingulatus & $130.9 \pm 11.9(9)$ & $143.6 \pm 7.3(5)$ & Insufficient no. \\
\hline \multicolumn{4}{|c|}{ Mean egg diam./female } \\
\hline A. fuscipes & $0.106 \pm 0.007(6)^{\ddagger}$ & $0.164 \pm 0.019(10)^{\ddagger}$ & Insufficient no. \\
\hline P. montanus & $0.34 \pm 0.03$ & $0.25 \pm 0.03(10)$ & $0.31 \pm 0.03(10)$ \\
\hline P. cingulatus & $0.37 \pm 0.04(9)$ & $0.29 \pm 0.04(5)$ & Insufficient no. \\
\hline
\end{tabular}

to early July) despite higher water temperatures, with a slightly contracted emergence period (mid-May to late September); and (iii) the larvae at Site 1, whereas they were present at a much higher density, were significantly $(P<0.05)$ smaller in their final instar (mean $\mathrm{HCW}=0.34 \pm 0.01,0.45 \pm 0.1,0.47$ at Sites 1,2 and 3, respectively) (Fig. 9).

Females of Philopotamus montanus moving upstream were the same size at all three sites, but those at Site 3 contained many more eggs, although these were 

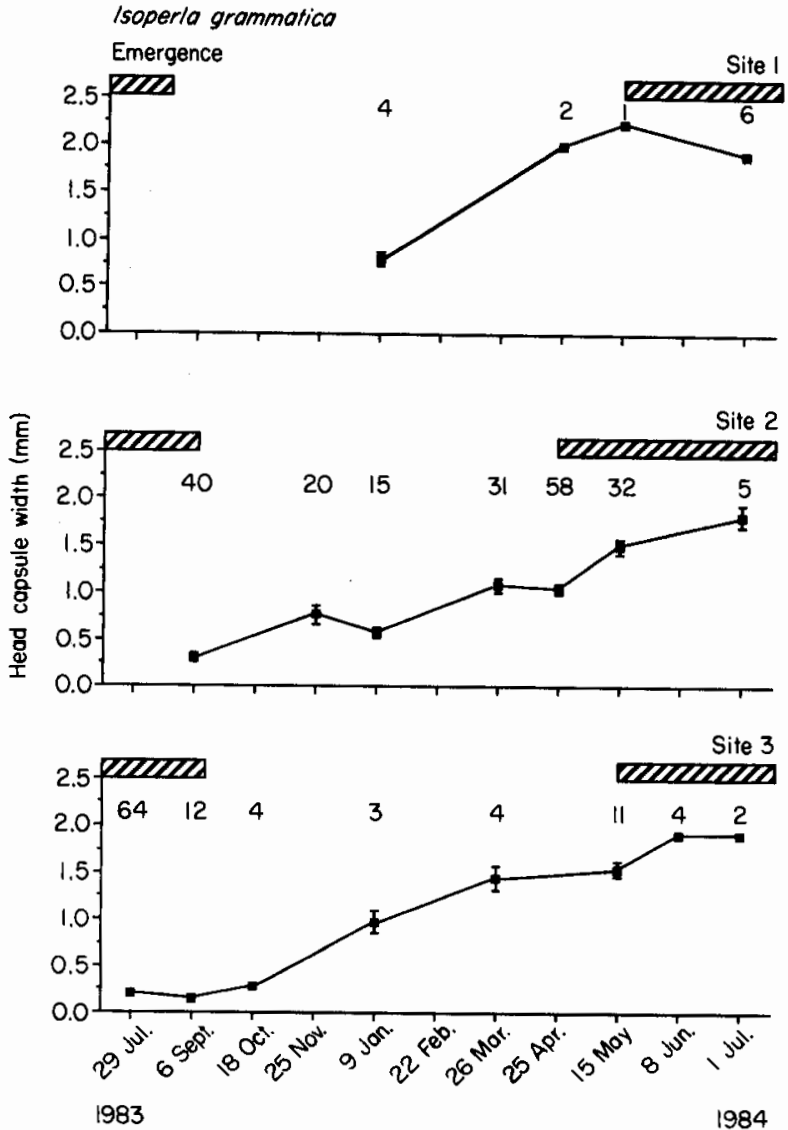

Fig. 8 Life history of the stonefly Isoperla grammatica at each of the three sites. Growth is shown as increase in head capsule width ( $\bar{x} \pm 1$ SE) over the period July 1983 to July 1984 . Extent of the emergence period is shown as a bar.

figure is reasonably representative of variation due to season and changes in water flow, then the calculated loss of larvae over the whole year, across the entire stream width, at this site was 3973 . This compares with 561 larvae and 965 larvae lost from Sites 2 and 3 , respectively. Since there were no significant differences in the numbers of females flying upstream or downstream at any of the three sites, a specific upstream compensatory flight cannot be invoked. Even greater downstream losses of immatures occurred in D. felix, B. rhodani and N. erratica (Table 7). None showed any evidence of upstream compensatory flight, although the percent upstream compensation by nymphs of $B$. rhodani at Site 2 was $88.3 \%$, and by nymphs of $N$. erratica at Site 3 was $62.5 \%$.

The loss of the most abundant non-insect species, G. pulex, to the drift was quite considerable at all three sites but especially at Site 1 (estimated to be
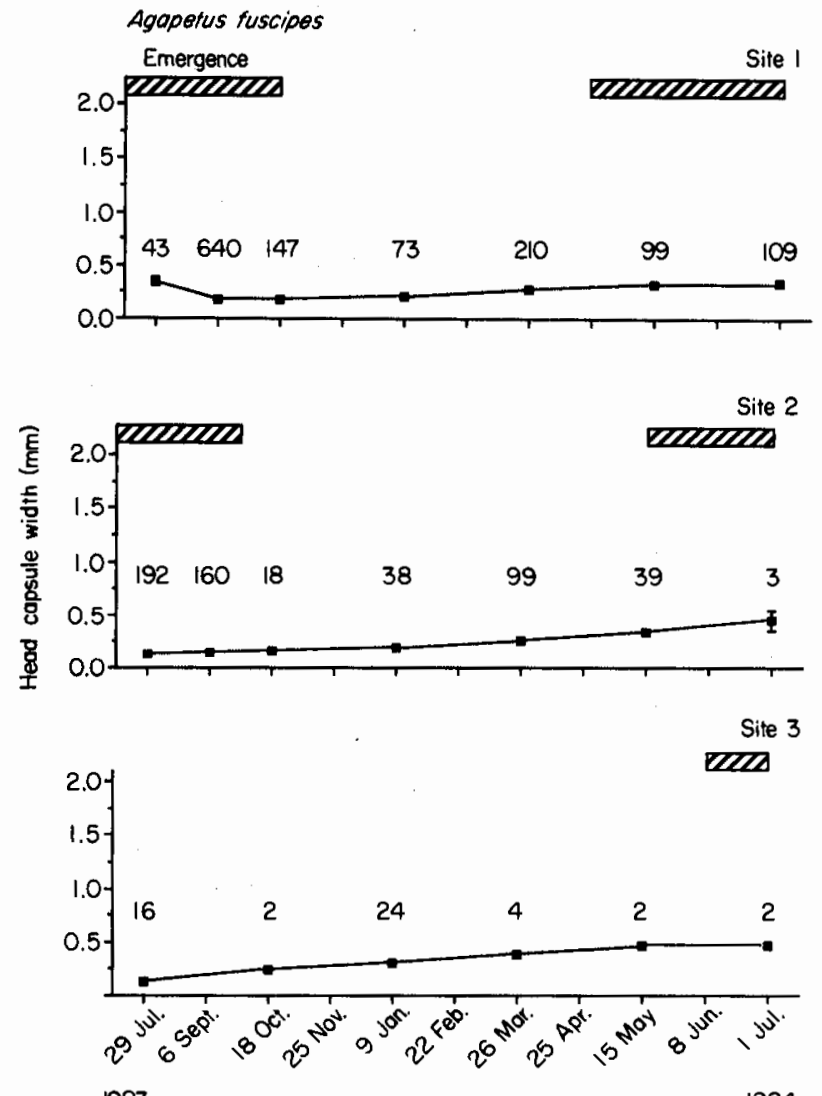

Fig. 9 Life history of the caddisfly Agapetus fuscipes at each of the three sites. Growth is shown as increase in head capsule width ( $\bar{x} \pm 1 \mathrm{SE}$ ) over the period July 1983 to July 1984 . Extent of the emergence period is shown as a bar.

137807 over the year, Table 7). However, at several times during the year, the numbers of amphipods moving upstream approached or exceeded those drifting downstream (Fig. 12). In fact, at Sites 1 and 3 there was a strong correlation between monthly mean benthic density and the percentage of drift loss compensated for by upstream migration $(r=0.641$ and 0.661 , respectively, $P<0.05$ ). In addition, at all sites, there was either no change or an increase in the benthic densities of amphipods between July 1983 and July 1984, the start and end of the study period. Clearly, upstream movement contributed to the recovery of benthic densities but this must have been aided by production of young over the long (10 months) reproductive period (see also Welton, 1979). Interestingly, the degree of upstream movement increased with distance from the stream source (Fig. 12). 


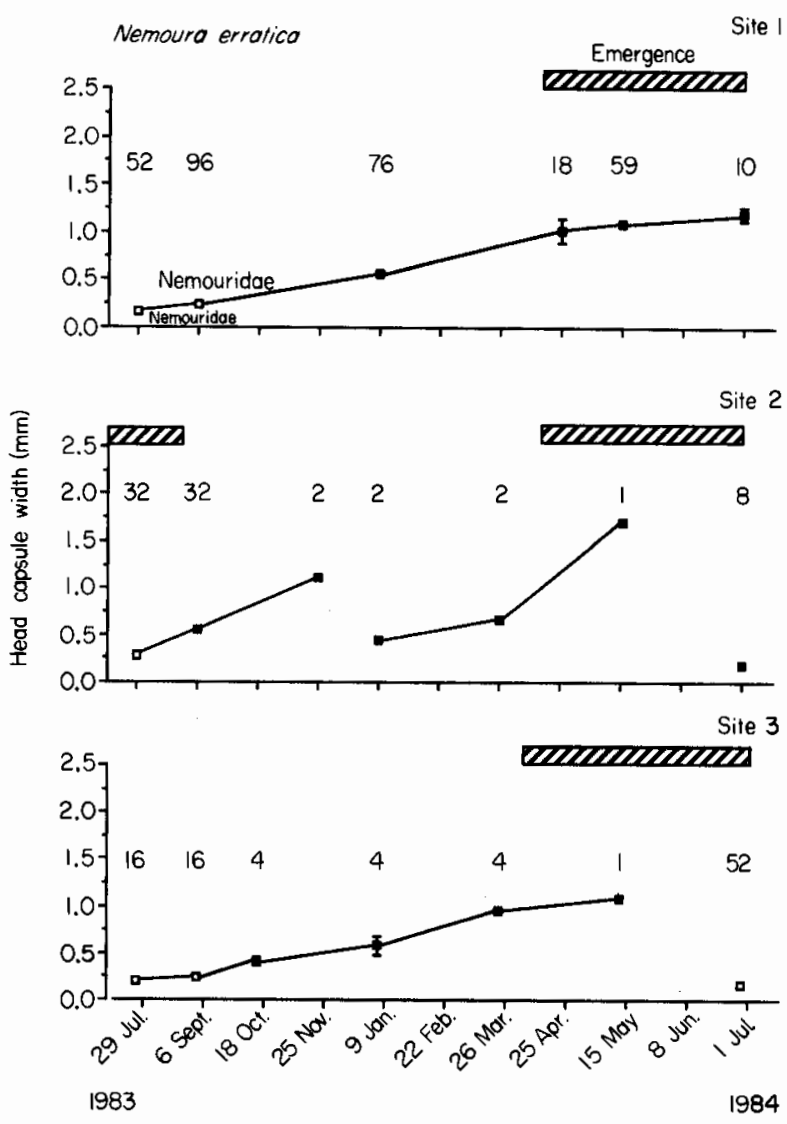

Fig. 6 Life history of the stonefly Nenoura erratica at each of the three sites. Growth is shown as increase in head capsule width ( $\bar{x} \pm 1 \mathrm{SE}$ ) over the period July 1983 to July 1984 . Note that many of the SE are too small to be distinguished from the symbol indicating the mean. The numbers of nymphs collected and measured on each data are shown above the growth curves. Extent of the emergence period is shown as a bar.

not different in size (Table 6). Most larvae were found at Sites 2 and 3. Final instar larvae at these two sites had head capsules approximately twice the width of those at Site 1 (Fig. 10). Moreover, final instar larvae were evident by the end of March at the downstream sites, but did not appear at Site 1 until June. The normally long emergence period (March to December) was contracted at Site 1 (April to November). Larvae of the next generation had appeared by late June at the two downstream sites, but were not evident until October at Site 1.

There were no differences detected in female size, the number of eggs carried or the mean egg diameter between adult Potamophylax cingulatus caught at Sites 1 and 2 (Table 6). Most of the larvae occurred at Site 2 and these, in their later instars, were significantly
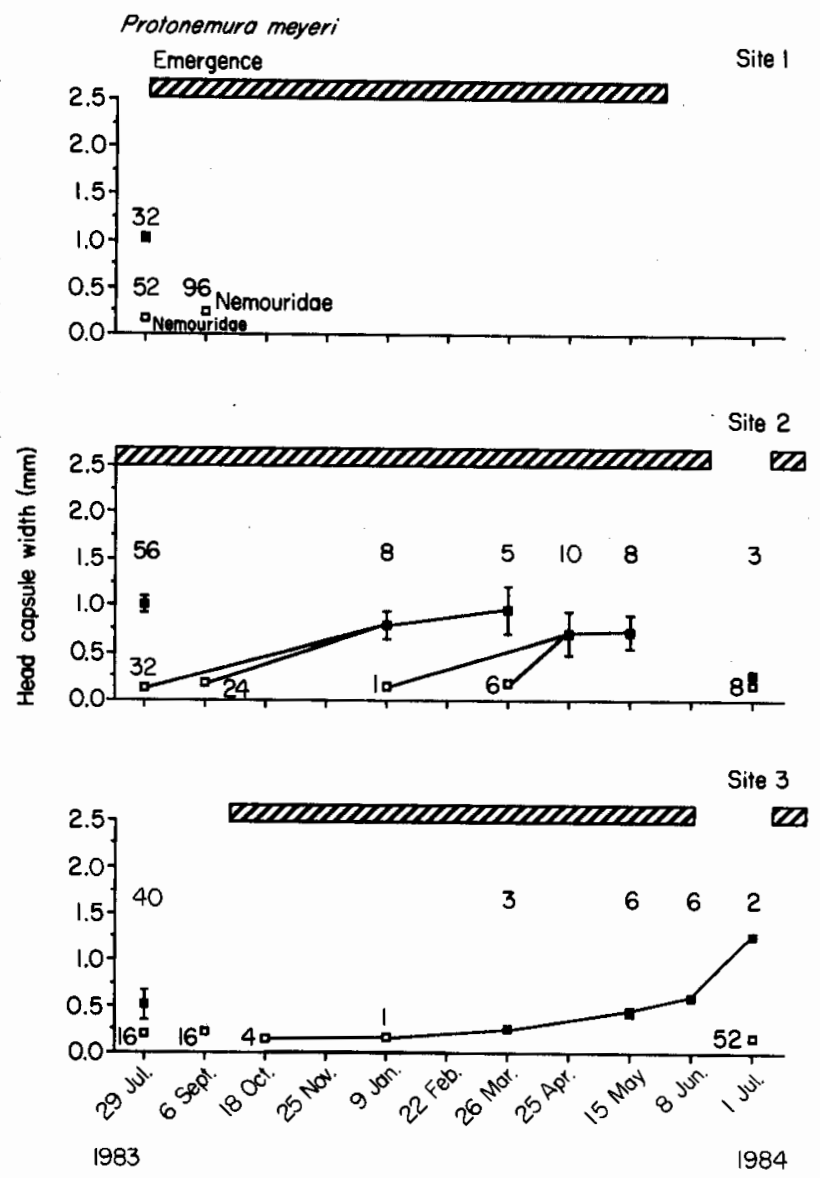

Fig. 7 Life history of the stonefly Protonemura meyeri at each of the three sites. Growth is shown as increase in head capsule width ( $\bar{x} \pm 1 \mathrm{SE}$ ) over the period July 1983 to July 1984 . Extent of the emergence period is shown as a bar.

smaller than those at the other two sites (Fig. 11). Patterns of larval growth appeared to differ among sites, but the small numbers obtained at certain times of the year make detailed comparison difficult.

Comparison of the upstream movement properties of insects versus non-insects

Estimates of the loss or gain of individuals to populations of representative species at the three sites are given in Table 7.

Among the insects, larvae of the caddisfly $A$. fuscipes showed an average of $63.6 \%$ replacement of individuals lost to the drift at Site 1 . During 39 days of sampling, spread over 1 year, fifty-one larvae were lost downstream from the $30 \mathrm{~cm}$ cross-section of stream sampled by the two traps. If we assume that this 


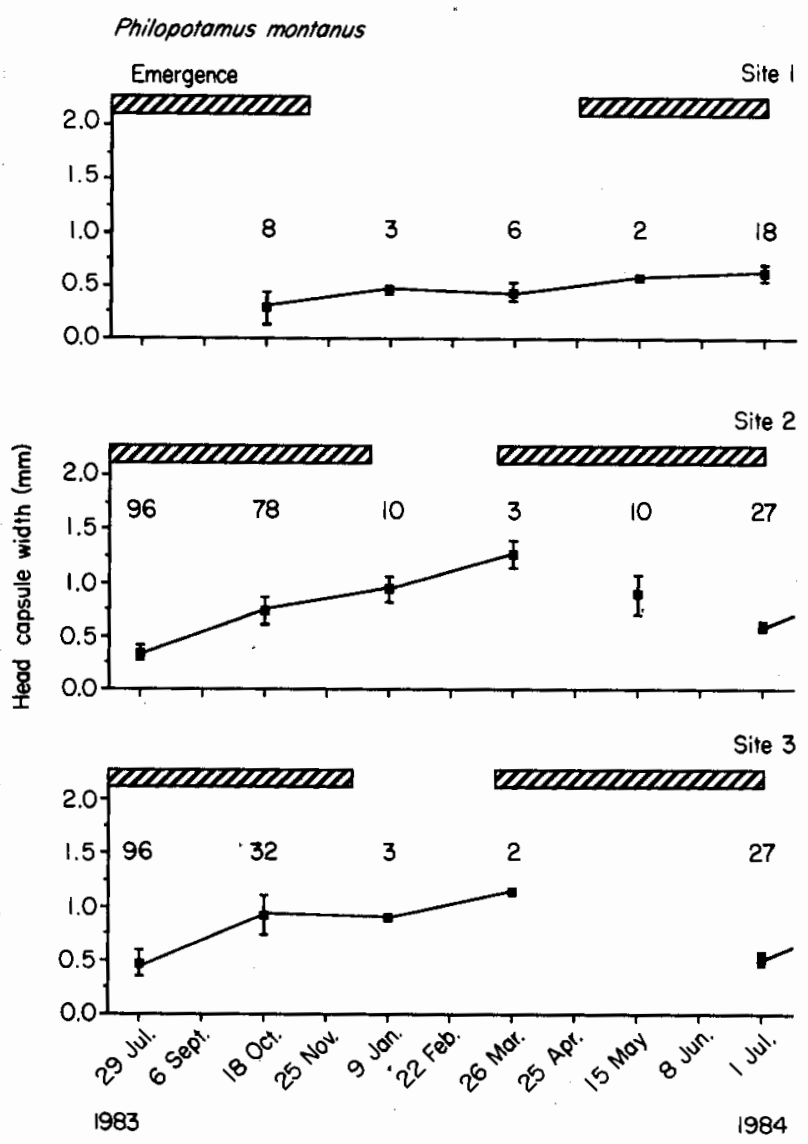

Fig. 10 Life history of the caddisfly Philopotanus montanus at each of the three sites. Growth is shown as increase in head capsule width ( $\bar{x} \pm 1 \mathrm{SE}$ ) over the period July 1983 to July 1984 . Extent of the emergence period is shown as a bar.

Polycelis felina was the only species to show a clear and consistent upstream migration. It is estimated that over the year there was a net gain of 22324 animals moving upstream at the Site 1 transect, and 912 animals at the Site 2 transect (Table 7). For the other flatworm, C. alpina, a loss by drift of 7730 individuals was estimated to have occurred at Site 1, but there was a gain of 1744 animals across the Site 2 transect.

A consistent downstream net loss of ostracods occurred at all sites, although a maximum of $50 \%$ upstream compensation was measured at Site 3 (Table 7).

\section{Discussion}

At both upstream sites (1 and 2), the numbers of invertebrates drifting downstream were related to
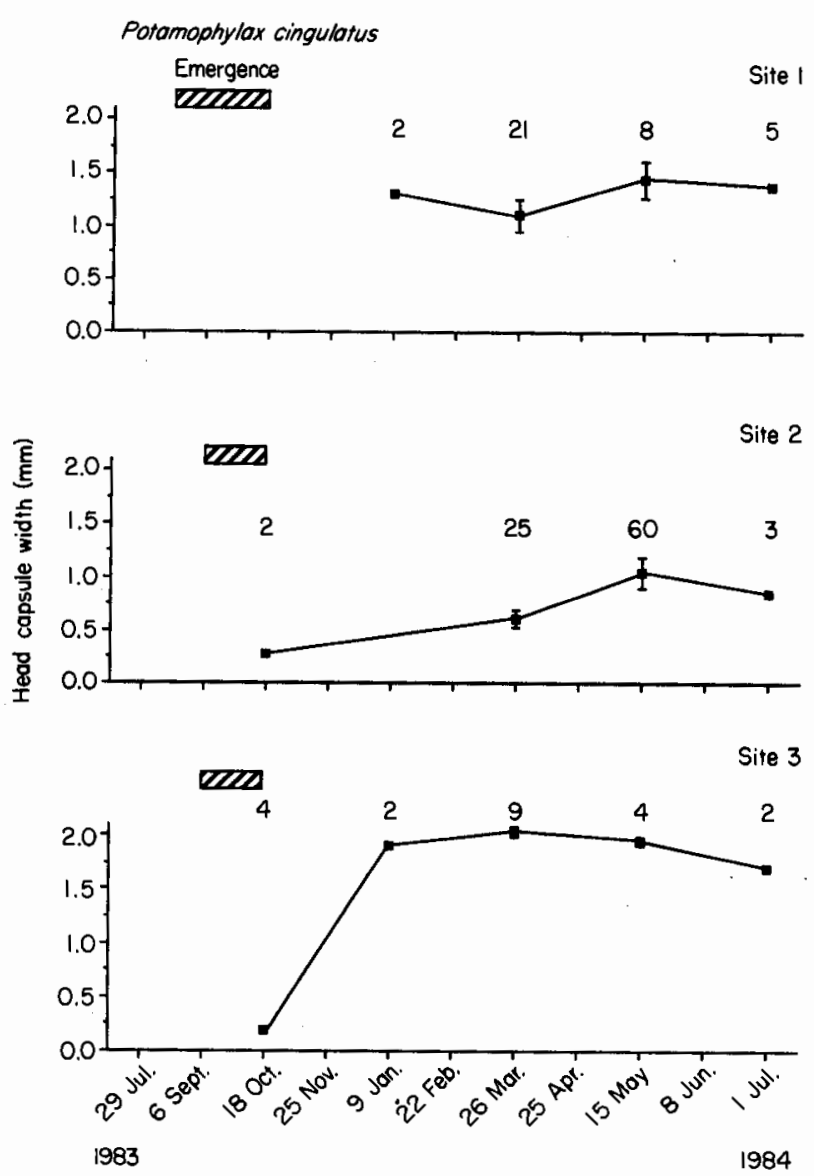

Fig. 11 Life history of the caddisfly Potamophylax cingulatus at each of the three sites. Growth is shown as increase in head capsule width ( $\bar{x} \pm 1 \mathrm{SE}$ ) over the period July 1983 to July 1984 Extent of the emergence period is shown as a bar.

current speed and water depth. Dramatic decreases in benthic densities at these two sites during September and October coincided with increases in the drift and may be indicative of animals being displaced downstream. In five out of six Hobbs and Butler traps, representing all three sites, there was a positive correlation between the numbers of animals moving downstream and the numbers moving upstream. This would seem to be evidence for a within-stream compensatory mechanism. However, at Site 1, over the year an average of only $19.3 \%$ compensation in total numbers was achieved. Taxa exhibiting higher compensatory migrations included species with headwater distributions, for example $P$. felina and $A$. fuscipes. Very high levels of upstream movements in flatworms have been recorded also by Light \& Adler (1983). Within-stream compensation at Site 2 


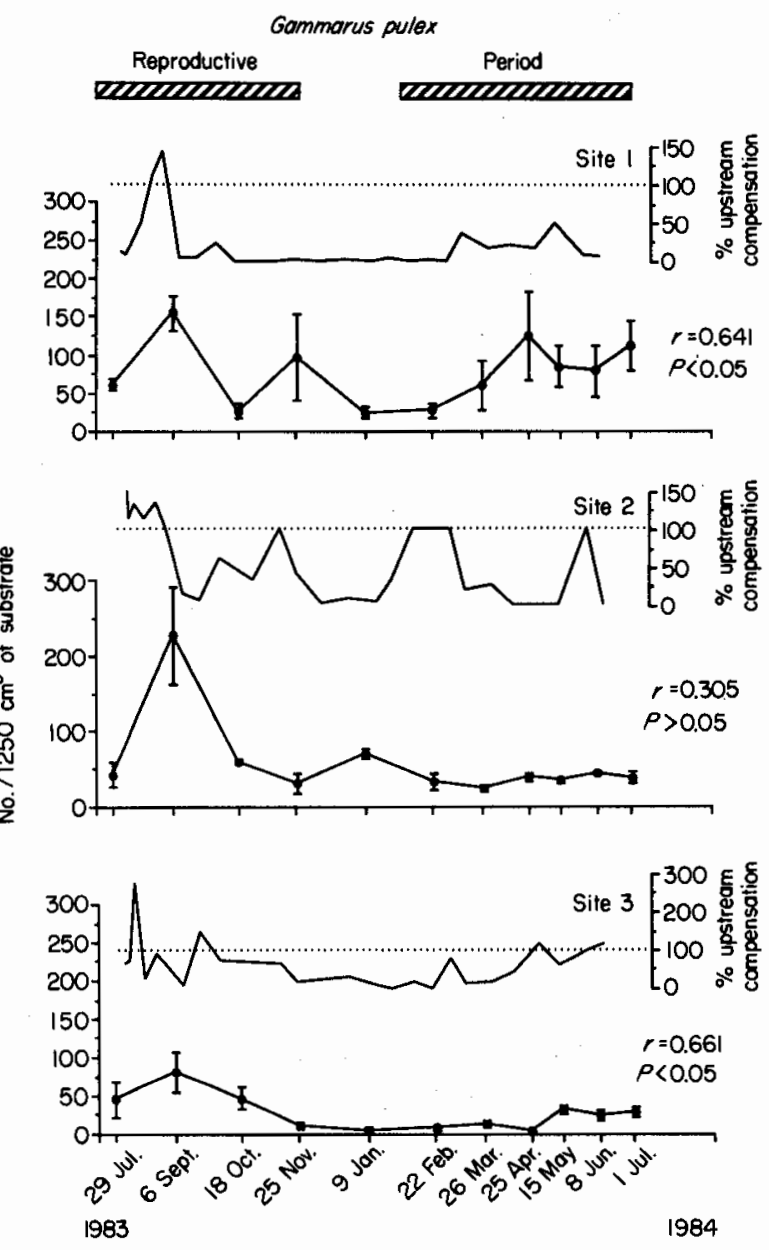

Fig. 12 Benthic densities (based on a substrate volume of $\left(1250 \mathrm{~cm}^{3}\right)$ of Gammarus pulex at the three sites $(\bar{x} \pm 1 \mathrm{SE})$.

Reproductive period, percentage compensation (as percentage numbers) of drifting individuals by upstream movement, and correlation coefficients between the latter and mean benthic densities are also shown.

was highly variable depending on trap location, but was again high in the flatworms and also in G. pulex, the black flies, chironomids, riffle beetles and $B$. rhodani. Elliott (1971) has reported upstream movement of $B$. rhodani nymphs in a Lake District stream and, in North America, upstream movement of $B$. vagans Mc.D. (an ecologically equivalent species) is thought to be achieved solely by the nymphs, as adults do not appear to fly upstream to oviposit (Waters, 1969; Bird \& Hynes, 1981). The highest average within-stream compensation occurred at Site $3(55.4 \%)$, which had the highest mean current speed $\left(\bar{x}=59.4 \pm 3.4 \mathrm{~cm} \mathrm{~s}^{-1}\right.$, compared with $43.7 \pm 2.3$ at Site 1 , and $47.9 \pm 4.7$ at Site 2). At Site 3, a variety of taxa exhibited high compensatory movement. Although a number of taxa showed poor compensatory movements (e.g. ostracods, Collembola and Plecoptera) few did so at all three sites.

The correlation between upstream movement and water temperature at Sites 2 and 3 was to be expected as the activity of many lotic invertebrates has been shown to be temperature dependent (Williams, 1990). Water temperature has been cited as an orientation cue for upstream migration in both nymphs of Parameletus (Ephemeroptera) (Söderstöm, 1988) and gammarids (Goedmaker \& Pinkster, 1981). Lack of correlation as Site 1 may have been the result of the narrower temperature range at the stream source; stenothermic populations may well respond indifferently to moderate flutuations in environmental temperature. Upstream movements of immatures have been shown to be seasonal in some taxa, especially mayflies (e.g. Neave, 1930; Hayden \& Clifford, 1974; Olsson \& Söderström, 1978), In Yr Ogof, some animals were caught whenever the traps were set, but the highest numbers moving upstream were during late August-mid-October, with a lesser peak during April and May.

Light \& Adler (1983) found a significant positive correlation between the numbers of female insects flying upstream and the proportion of benthos (including non-insects?) in the drift in a hardwater stream in Pennsylvania. We found no such correlation, although the positive correlation between the numbers of invertebrates drifting and moving upstream at all three sites (but at only one trap at Site 3) does suggest a regulating mechanism. Although it has been argued that upstream movement may have evolved to counteract drift, it is conceivable that it may simply be another, quite distinct, dispersal mechanism (Söderström, 1987). We found no relationship between adult flight direction and wind, but the latter has been deemed to be influential in some other streams (Elliott, 1967; Bishop \& Hynes; $1969 b)$.

Of nine major aquatic insect groups living in the headwaters of Yr Ogof, the adults of six showed strong upstream flight tendencies at one or more of three sites. This appears to lend support to the compensatory flight hypothesis. However, within most groups this trend was inconsistent among sites, or made little biological sense. For example, in four families of Diptera, adults flew beyond the source of 


\begin{tabular}{|c|c|c|c|}
\hline Taxon & Site 1 & Site 2 & Site 3 \\
\hline \multicolumn{4}{|l|}{ Agapetus fuscipes } \\
\hline Total no. larvae trapped over 39 days & 193 & 26 & 33 \\
\hline$\%$ upstream compensation by larvae & 63.6 & 30.0 & 37.5 \\
\hline $\begin{array}{l}\text { Measured net loss or gain of individuals } \\
\text { (through traps), over } 39 \text { days }\end{array}$ & -51 & -18 & -21 \\
\hline Estimated net loss or gain across the entire & & & \\
\hline width of the stream, over $1 \mathrm{yr}$ & -3973 & -561 & -965 \\
\hline Predominant upstream flight by females & No & No & No \\
\hline \multicolumn{4}{|l|}{ Diplectrona felix } \\
\hline Total no. larvae trapped over 39 days & 104 & 59 & 29 \\
\hline$\%$ upstream compensation by larvae & 25.3 & 7.3 & 31.8 \\
\hline Measured net loss or gain or individuals & & & \\
\hline (through traps), over 39 days & -78 & -55 & -20 \\
\hline Estimated net loss or gain across the entire & & & \\
\hline width of the stream, over $1 \mathrm{yr}$ & -6055 & -1704 & -925 \\
\hline Predominant upstream flight by females & No & No & No \\
\hline \multicolumn{4}{|l|}{ Baetis rhodani } \\
\hline Total no. nymphs trapped over 39 days & 207 & 785 & 533 \\
\hline$\%$ upstream compensation by nymphs & 42.8 & 88.3 & 31.5 \\
\hline $\begin{array}{l}\text { Measured net loss or gain of individuals } \\
\text { (through traps), over } 39 \text { days }\end{array}$ & -118 & -92 & -365 \\
\hline Estimated net loss or gain across the entire & -118 & & -365 \\
\hline width of the stream, over 1 year & -9196 & -2864 & -17085 \\
\hline Predominant upstream flight by females & $*$ & No & No \\
\hline \multicolumn{4}{|l|}{ Nenoura erratica } \\
\hline Total no. nymphs trapped over 39 days & 311 & 79 & 102 \\
\hline$\%$ upstream compensation by nymphs & 29.3 & 19.5 & 62.5 \\
\hline Measured net loss or gain of individuals & & & \\
\hline (through traps), over 39 days & -220 & -64 & -49 \\
\hline Estimated net loss or gain across the entire & & & \\
\hline width of the stream, over $1 \mathrm{yr}$ & -17151 & -1994 & -2292 \\
\hline Predominant upstream flight by females & No & No & No \\
\hline \multicolumn{4}{|l|}{ Ganmmarus pulex } \\
\hline Total no. trapped over 39 days & 2117 & 867 & 1047 \\
\hline$\%$ upstream compensation & 16.5 & 56.5 & 61.8 \\
\hline $\begin{array}{l}\text { Measured net loss or gain of individuals } \\
\text { (through traps), over } 39 \text { days }\end{array}$ & -1768 & -377 & -400 \\
\hline $\begin{array}{l}\text { Estimated net loss or gain across the entire } \\
\text { width of the stream, over } 1 \mathrm{yr}\end{array}$ & -137803 & -11754 & -18715 \\
\hline \multicolumn{4}{|l|}{ Polycelis felina } \\
\hline Total no. trapped over 39 days & 149 & 13 & * \\
\hline$\%$ upstream compensation & 192.2 & 225.0 & $*$ \\
\hline $\begin{array}{l}\text { Measured net loss or gain of individuals } \\
\text { (through traps), over } 39 \text { days }\end{array}$ & +286 & +29 & * \\
\hline Estimated net loss or gain across the entire & & & \\
\hline width of the stream, over $1 \mathrm{yr}$ & +22324 & +912 & * \\
\hline \multicolumn{4}{|l|}{ Crenobia alpina } \\
\hline Total no. trapped over 39 days & 150 & 42 & * \\
\hline$\%$ upstream compensation & 33.9 & 133.3 & $*$ \\
\hline $\begin{array}{l}\text { Measured net loss or gain of individuals } \\
\text { (through traps), over } 39 \text { days }\end{array}$ & -99 & +56 & * \\
\hline $\begin{array}{l}\text { Estimated net loss or gain across the entire } \\
\text { width of the stream, over } 1 \mathrm{yr}\end{array}$ & +7730 & +1744 & * \\
\hline \multicolumn{4}{|l|}{ Ostracoda } \\
\hline Total no. trapped over 39 days & 176 & 72 & 30 \\
\hline$\%$ upstream compensation & 11.4 & 2.9 & 50.0 \\
\hline $\begin{array}{l}\text { Measured net loss or gain of individuals } \\
\text { (through traps), over } 39 \text { days }\end{array}$ & -156 & -70 & -15 \\
\hline $\begin{array}{l}\text { Estimated net loss or gain across the entire } \\
\text { width of the stream, over } 1 \mathrm{yr}\end{array}$ & -1299 & -233 & -75 \\
\hline
\end{tabular}

Table 7 Estimates of the loss (-) or gain $(+)$ of individuals to the populations of representative species at the three sites $\left({ }^{*}\right.$, very few animals collected) 
the stream, whereas other groups flew upstream at one site but downstream at another site only $100 \mathrm{~m}$ away. The females of some species (e.g. Agapetus fuscipes) moving upstream were bigger and contained more and larger eggs than females moving downstream, but only at some sites.

A greater level of resolution of the data showed that a longitudinal zonation occurred amongst both the Plecoptera and Trichoptera. Species with immature stages primarily concentrated at the uppermost site (Site 1) did not show female flight patterns that were consistent with maintaining a headwater distribution. Among eighteen common species, the females of only six showed strong directional flight. Of these, only one, Silo pallipes, flew predominantly upstream-yet most of its larvae were concentrated downstream. Females of another caddisfly, Tinodes assimilis, and of the stonefly Nemoura erratica also flew predominantly in directions opposite to those in which the greatest densities of their immatures were located. Lack of consistent flight direction preference among sites could be interpreted as being appropriate to maintain a wide distribution of immatures, for example in Siphonoperla torrentium (Pictet). Flights upstream of the source, as seen in many of the species in $\mathrm{Yr}$ Ogof, and upstream of the main concentration of their larvae, as in Silo pallipes, are difficult to interpret in terms of oviposition efficiency in this particular stream. These findings largely conflict with those reviewed by Müller (1982) who reported as many as $77.5 \%$ of the adults of the caddisfly Cheumatopsyche lepida Pictet on the downstream side (i.e. moving upstream) of a Malaise trap set on the River Dalälven in Sweden. In addition, $76.5 \%$ of the adults of $I$. grammatica emerging at the mouth of the River Ängeran were caught moving upstream (Müller, 1982). As in Yr Ogof, most of the adult insects emerging in Roy's Creek, Montana, showed no directional flight preference (Jones \& Resh, 1988).

One of the fundamental arguments for the existence of upstream compensatory flights is that they provide a means of restoring and perpetuating the longitudinal distribution patterns seen in benthic stages. However, where a species extends over a substantial length of stream bed, is it reasonable to assume that its biology remains uniform? We submit that some sections of stream, within a species' normal distribution range, provide more suitable habitat than others. Identification of such optimal habitats for species living in Yr Ogof, based on a comparison of life histories at different sites, proved difficult, particularly amongst the Trichoptera, as there appeared to be more than one measure of habitat suitability. For example, in terms of supporting maximum numbers of Agapetus fuscipes larvae, Site 1 appeared best. However, although the larvae developed faster here, final instar larvae were smaller than at Sites 2 and 3 ( $P<0.05$, from $t$-tests) where densities were much lower. The occurrence of larger, but fewer, final instar larvae at Site 2 followed through to the production of larger females each containing twice the number of eggs which were also larger. Possibly the population at Site 1 was food limited whereas those at the other two sites were space limited. A similar pattern was evident in the larvae of $P$. cingulatus which, although most numerous at Site 2, were almost twice the size at Sites 1 and 3 . In the case of Philopotamus montanus, the greater numbers of larger larvae supported at Sites 2 and 3, clearly suggests that Site 1 provided suboptimal conditions for this species. Interpreted in terms of Vannote and Sweeney's Thermal Equilibrium Hypothesis (Vannote \& Sweeney, 1980), these data indicate that, for $P$. montanus, Sites 2 and 3 represent this species' thermal optimum (annual range $1.5-20^{\circ} \mathrm{C}$ ) in this system. Determination of optimal thermal regimes is more difficult in the cases of $A$. fuscipes and $P$. cingulatus, however, as locations of maximum individual larval weight and adult fecundity, and maximum larval densities did not coincide.

For the stoneflies, there were no differences in the sizes of final instar nymphs within a species among sites, although there were differences in growth rates at certain times of the year. Presumably, those sites that supported maximum densities of nymphs could be interpreted as representing optimal habitat.

In view of the large size differences among adults of both $P$. cingulatus and $P$. montanus emerging from the different sites, it is logical to suggest that this could affect the potential for interbreeding, due to disparate sizes of male and female genitalia. Recent studies (e.g. Jackson \& Resh, 1992) have shown genetic differences among sympatric populations of the same caddisfly species living in the same drainage basin. Could such differences, resulting in genetic isolation, occur on a much smaller scale, measured perhaps in hundreds of metres? Might not this form of isolation promote local mating (and oviposition?), 
selecting against long distance compensatory flights prior to mating? However, it could be hypothesized that stronger females might be more likely to make post-copulatory upstream flights. Clearly, there is scope for further work here.

Longitudinal zonation in running waters results from microhabitat selection by immature stages after eggs have been laid (or young have been deposited) by females. In some aquatic invertebrate species, oviposition/deposition sites are carefully selected by the females (e.g. mosquitoes). In others, e.g. Gammarus pseudolimnaeus Bousfield, juveniles have been shown to be relegated to what appear to be suboptimal microhabitats by adults (Williams \& Moore, 1986). The latter situation is not uncommon in invertebrates, particularly in terrestrial hemimetabolous insects (Price, 1975). In aquatic insects where, typically, the adult stage lives in a different habitat from the immatures such intraspecific competition should be rare. On the grounds of ecological efficiency, however, it is reasonable to assume that adult lotic insects will lay their eggs in suitable larval/nymphal habitats. While it is true that very few headwater species will oviposit in large rivers or in ponds, little information is available as to where females lay eggs along a stretch of stream containing both optimal and suboptimal larval/nymphal habitats. It is known, however, that some hydropsychid caddisflies and black flies select smooth, clean substrates for oviposition (Imhof \& Smith, 1979; Deutsch, 1984). We suggest that, in Yr Ogof, females oviposit both in the vicinity of their emergence site and after flying variable distances both upstream and downstream. The seemingly inappropriate flight behaviour observed in many of the Yr Ogof females may be a consequence of the small-scale/high-resolution nature of this study. Such behaviour would seem to be inefficient in terms of energy used in moving away from habitats suitable for larval development. However, this apparent loss of individual fitness may be adaptive if 'risk is spread' among related females by simultaneous flight in opposite directions. This is seen in virtually all lotic insect populations studied to date and results in the spread of species to adjacent habitats and the maintenance of broad upland/lowland distributions.

We question the general applicability of the compensatory upstream flight hypothesis because in none of the species studied in Yr Ogof did females show an upstream flight preference appropriate for maintaining upstream populations of immatures. Further, many species exhibited flight directions that appeared inappropriate in linking oviposition flight direction with site of maximum benthic density, and others were totally at odds with what would have been predicted in order to maintain the observed longitudinal zonation patterns. Although some lotic insect species may indeed be predisposed to fly upstream (or downstream), this trait was not singularly expressed in the populations studied here. We conclude that maintenance of insect population zonation in $\mathrm{Yr}$ Ogof results from oviposition by randomly flying, locally emerged females. Selection for longdistance upstream fliers (in order to repopulate headwaters) might not be as strong as expected as longdistance fliers emerging from headwater regions would tend to fly beyond suitable larval habitat.

Longitudinal zonation in non-insects is proposed to be maintained through a combination of strong (but often seasonal) positive rheotaxis combined with long (longer than most insect) reproductive periods. One factor that we did not measure in our study was the distance moved, both upstream, by aquatic stages. Elliott (1971) has shown for G. pulex, for example, that, during a day, animals might move from 1 to $10 \mathrm{~m}$ downstream and from 0 to $14 \mathrm{~m}$ upstream. The latter indicates that submerged upstream movement, in some species, may more than compensate for drift (see also Bergey \& Ward, 1989). Compensatory mechanisms for the replacement of upstream populations of small organisms that had high displacement rates downstream in Yr Ogof (e.g. ostracods) are unknown, although some similar sized organisms (harpacticoids) had very good upstream movement capabilities.

\section{Acknowledgments}

We thank the Jones family of Glyn Farm, Aber for allowing us to work on their property, Dr Nick Ellis for allowing us access to Yr Ogof, and Professor Noel Hynes for a critical reading of the MS. Marilyn Smith, Kathy Moore, Gerry Dunn, Susan Dix and Edward Evans provided excellent technical assistance. Dr Maurice Lock supplied office and laboratory space, and the School of Biological Sciences, University of Wales, Bangor provided logistic support. The project 
was funded by the Natural Sciences and Engineering Research Council of Canada.

\section{References}

Benson L.J. \& Pearson R.G. (1987) Drift and upstream movement in Yuccabine Creek, an Australian tropical stream. Hydrobiologia, 153, 225-239.

Bergey E.A. \& Ward J.V. (1989) Upstream-downstream movements of aquatic invertebrates in a Rocky Mountain stream. Hydrobiologia, 185, 71-82.

Bird G.A. \& Hynes H.B.N. (1981) Movements of adult aquatic insects near streams in Southern Ontario. Hydrobiologia, 77, 65-69.

Bishop J.E. \& Hynes H.B.N. (1969a) Upstream movements of the benthic invertebrates in the Speed River, Ontario. Journal of the Fisheries Research Board of Canada, 26, 279-298.

Bishop J.E. \& Hynes H.B.N. (1969b) Downstream drift of the invertebrate fauna of a stream ecosystem. Archiv für Hydrobiologie, 66, 59-90.

Deutsch W.G. (1984) Oviposition of Hydropsychidae (Trichoptera) in a large river. Canadian Journal of Zoology, 62, 1988-1994.

Elliott J.M. (1967) Invertebrate drift in a Dartmoor stream. Archiv fur Hydrobiologie, 63, 202-237.

Elliott J.M. (1971) Upstream movements of benthic invertebrates in a Lake District stream. Journal of Animal Ecology, 40, 235-252.

Goedmaker A. \& Pinkster S. (1981) Population dynamics of three Gammarid species (Crustacea, Amphipoda) in a French chalk stream. Part III. Migration. Bijdragen tot de Dierkunde, 51, 145-180.

Hayden W. \& Clifford H.F. (1974) Seasonal movements of the may fly Leptophlebia cupida (Say) in a brownwater stream of Alberta, Canada. Ainerican Midland Naturalist, 91, 90-102.

Hemsworth R.J. \& Brooker M.P. (1979) The rate of downstream displacement of macroinvertebrates in the upper Wye, Wales. Holarctic Ecology, 2, 130-136.

Hildrew A.G. \& Townsend C.R. (1980) Aggregation, interference and foraging by larvae of Plectrocnemia conspersa (Trichoptera: Polycentropodidae). Animal Behaviour, 28, 553-560.

Hobbs H.H. \& Butler M.J. (1981) A sampler for simultaneously measuring drift and upstream movements of aquatic macroinvertebrates. Journal of Crustacean Biology, 1, 63-69.

Imhoff J.E. \& Smith S.M. (1979) Oviposition behaviour, egg masses and hatching response of the eggs of five Nearctic species of Simulium (Diptera: Simuliidae). Bulletin of Entomological Research, 69, 405-425.
Jackson J.K. \& Resh V.H. (1992) Variation in genetic structure among populations of the caddisfly Helicopsyche borealis from three streams in northern California, U.S.A. Freshwater Biology, 27, 29-42.

Jones T.S. \& Resh V.H. (1988) Movements of adult aquatic insects along a Montana (USA) Springbrook. Aquatic Insects, 10, 99-104.

Light R.W. \& Adler P.H. (1983) Predicting the colonization cycle of aquatic invertebrates. Freshwater Invertebrate Biology, 2, 74-87.

Madsen B.L., Bengtsson J. \& Butz I. (1973) Observations on upstream migration by imagines of some Plecoptera and Ephemeroptera. Limnology and Oceanography, 18, 678-681.

Malaise R. (1937) A new insect-trap. Entomologica Tidskrift, 58, 148-160.

Mendl H. \& Müller K. (1979) Upstream and downstream flight movements of Amphinemura borealis Morton (Ins.: Pleoptera), compared by means of captures in several methods. Aquilo Series Zoologica, 19, 1-3.

Mottram J.C. (1932) The living drift of rivers. Transactions of the Newbury District Field Club, 6, 195-198.

Muiller K. (1954) Investigations on the organic drift in North Swedish streams. Report of the Institute of Freshwater Research, Drottningholm, 35, 133-148.

Müller K. (1982) The colonization cycle of freshwater insects. Oecologia, 52, 202-207.

Neave F. (1930) Migratory habits of the mayfly Blasturuus cupidus Say. Ecology, 11, 568-576.

Olsson T. \& Söderström O. (1978) Springtime migration and growth of Parameletus chelifer (Ephemeroptera) in a temporary stream in northern Sweden. Oikos, 31, 284-289.

Price P.W. (1975) Insect Ecology. John Wiley \& Sons, New York.

Söderström O. (1987) Upstream movements of invertebrates in running waters-a review. Archiv fur Hydrobiologie, 111, 197-208.

Söderström O. (1988) Environmental cues used in upstream orientation by Parameletus chelifer and $P$. minor (Ephemeroptera) nymphs; an experimental study. Hydrobiologia, 162, 235-241.

Vannote R.L. \& Sweeney B.W. (1980) Geographic analysis of thermal equilibria: A conceptual model for evaluating the effect of natural and modified thermal regimes on aquatic insect communities. American Naturalist, 115, 667-695.

Walton O.E. (1980) Invertebrate drift from predatorprey associations. Ecology, 61, 1486-1497.

Waters T.F. (1969) Invertebrate drift ecology and significance to stream fishes. Symposium on Salmon and Trout in Streams (Ed. by T.G. Northcote), pp. 121-134. H.R. Macmillan Lectures in Fisheries, University of 
British Columbia, Vancouver.

Welton J.S. (1979) Life-history and production of the amphipod Gammarus pulex in a Dorset chalk stream. Freshwater Biology, 9, 263-275.

Williams D.D. (1990) A field study of the effects of water temperature, discharge and trout odour on the drift of stream invertebrates. Archiv für Hydrobiologie, 119. $167-181$.

Williams D.D. \& Feltmate B.W. (1992) Aquatic Insects.
C.A.B. International, Wallingford, $358 \mathrm{pp}$.

Williams D.D. \& Moore K.A. (1986) Microhabitat selection by a stream-dwelling amphipod: a multivariate analysis approach. Freshwater Biology, 16, 115-122.

(Manuscript accepted 15 March 1993) 